\title{
Rax Is a Selector Gene for Mediobasal Hypothalamic Cell Types
}

\author{
Fuqu Lu, ${ }^{1 \star}$ Deepon Kar, ${ }^{1 *}$ Nicole Gruenig, ${ }^{1}$ Zi Wei Zhang, ${ }^{1}$ Nicole Cousins, ${ }^{1}$ Helen M. Rodgers, ${ }^{2}$ Eric C. Swindell, ${ }^{3}$ \\ Milan Jamrich, ${ }^{4}$ Carol Schuurmans, ${ }^{5}$ Peter H. Mathers, ${ }^{6}$ and Deborah M. Kurrasch ${ }^{1}$ \\ ${ }^{1}$ Department of Medical Genetics, Alberta Children's Hospital Research Institute, Hotchkiss Brain Institute, University of Calgary, Calgary, Alberta T2N \\ 4N1, Canada, ${ }^{2}$ Neuroscience Graduate Program, West Virginia University School of Medicine, Morgantown, West Virginia 26506, ${ }^{3}$ Department of \\ Pediatrics, The University of Texas Medical School at Houston, Houston, Texas 77030, ${ }^{4}$ Departments of Molecular and Cellular Biology, Molecular and \\ Human Genetics, Baylor College of Medicine, Houston, Texas 77030, ${ }^{5}$ Department of Biochemistry and Molecular Biology, Hotchkiss Brain Institute, \\ Alberta Children's Hospital Research Institute, University of Calgary, Calgary, Alberta T2N 1N4, Canada, and ${ }^{6}$ Departments of Otolaryngology, \\ Biochemistry, and Ophthalmology, West Virginia University School of Medicine, Morgantown, West Virginia 26506
}

The brain plays a central role in controlling energy, glucose, and lipid homeostasis, with specialized neurons within nuclei of the mediobasal hypothalamus, namely the arcuate (ARC) and ventromedial (VMH), tasked with proper signal integration. Exactly how the exquisite cytoarchitecture and underlying circuitry becomes established within these nuclei remains largely unknown, in part because hypothalamic developmental programs are just beginning to be elucidated. Here, we demonstrate that the Retina and anterior neural fold homeobox (Rax) gene plays a key role in establishing ARC and VMH nuclei in mice. First, we show that Rax is expressed in ARC and VMH progenitors throughout development, consistent with genetic fate mapping studies demonstrating that Rax+ lineages give rise to VMH neurons. Second, the conditional ablation of Rax in a subset of VMH progenitors using a Shh::Cre driver leads to a fate switch from a VMH neuronal phenotype to a hypothalamic but non-VMH identity, suggesting that Rax is a selector gene for VMH cellular fates. Finally, the broader elimination of Rax throughout ARC/VMH progenitors using Six3::Cre leads to a severe loss of both VMH and ARC cellular phenotypes, demonstrating a role for Rax in both VMH and ARC fate specification. Combined, our study illustrates that Rax is required in ARC/VMH progenitors to specify neuronal phenotypes within this hypothalamic brain region. Rax thus provides a molecular entry point for further study of the ontology and establishment of hypothalamic feeding circuits.

\section{Introduction}

The tuberal hypothalamus is comprised of three interconnected nuclei: the dorsomedial (DMH), ventromedial (VMH), and arcuate (ARC). While each of these nuclei mediates a variety of physiologies, they share a role in the regulation of energy balance and can function in an integrated fashion.

Development of the tuberal hypothalamus is divided into four main events: (1) regionalization of the tuberal prosencephalic territory [before embryonic day (E) 10.5]; (2) specification and differentiation of DMH, VMH, and ARC progenitors (E10.5-

\footnotetext{
Received Feb. 24, 2012; revised 0ct. 13, 2012; accepted 0ct. 29, 2012

Author contributions: F.L., D.K., N.G., Z.W.Z., H.M.R., P.H.M., and D.M.K. designed research; F.L., D.K., N.G., Z.W.Z., N.C., and H.M.R. performed research; E.C.S., M.J., C.S., and P.H.M. contributed unpublished reagents/analytic tools; F.L., D.K., C.S., P.H.M., and D.M.K. analyzed data; D.M.K. wrote the paper.

This work was supported by Canadian Institutes of Health Research (CIHR) Grant MOP-275053 and Alberta Children's Hospital Foundation to D.M.K., Nation Intitutes of Health Grant EY012152 to P.H.M., and CIHR MOP-44094 to C.S. We thank Dr. Clement Cheung (University of California, San Francisco) for technical assistance with sectioning and in situ hybridization and our colleagues at the University of Calgary, Drs. Sarah Childs and Sarah McFarlane, for useful discussions and sharing of reagents.

*F.L. and D.K. contributed equally to this work.

The authors declare no competing financial interests.

Correspondence should be addressed to Deborah M. Kurrasch, Department of Medical Genetics, Alberta Children's Hospital Research Institute, Hotchkiss Brain Institute, University of Calgary, 3330 Hospital Drive NW, Room HS2275, Calgary, AB T2N 4N1, Canada. E-mail: kurrasch@ucalgary.ca.

DOI:10.1523/JNEUROSCI.0913-12.2013

Copyright $\odot 2013$ the authors $\quad 0270-6474 / 13 / 330259-14 \$ 15.00 / 0$
}

E15.5); (3) neuronal migration (E10.5-E15.5) and (4) coalescing of neurons into organized nuclei (nucleogenesis; E16.5-E18.5; Ifft, 1972; Shimada and Nakamura, 1973; Altman and Bayer, 1986; Caqueret et al., 2005, 2006; McClellan et al., 2006). By E9.5, just before the onset of neurogenesis, the presumptive hypothalamus has acquired a regional identity by the combinatorial actions of extracellular signals (e.g., morphogens such as Shh) and intrinsic factors (e.g., homeodomain transcription factors, such as Nkx2.1, Six3). Six 3 is required to initiate Shh expression in the forebrain (Geng et al., 2008) with the deletion of Six3 resulting in widespread truncations of forebrain territories (including hypothalamic; Lagutin et al., 2003). Shh is required to initiate expression of the homeodomain factor Thyroid transcription factor 1 (Nkx2.1; also known as Ttf1) in hypothalamic progenitors, conferring a ventral prosencephalic identity (Sussel et al., 1999; Marín et al., 2002; Manning et al., 2006; Szabó et al., 2009b). Once a hypothalamic regional territory is established, its multipotent progenitors acquire subtype-specific identities, the molecular determinants of which are beginning to be uncovered (McNay et al., 2006; Kim et al., 2008; Padilla et al., 2010; Pelling et al., 2011).

Rax is a paired-type homeobox gene best studied for its role in vertebrate eye formation (Furukawa et al., 1997; Mathers et al., 1997; Tucker et al., 2001; Andreazzoli et al., 2003; Loosli et al., 2003; Kennedy et al., 2004; Voronina et al., 2004; Muranishi et al., 2011). During gastrulation (E7.5), Rax is expressed in a territory that gives 
rise to the retina, optic stalk, and ventral hypothalamus (Furukawa et al., 1997; Mathers et al., 1997; Muranishi et al., 2012). Gain-of-function and loss-of-function studies in retina show a role for Rax in tissue and cell specification and in progenitor maintenance (Furukawa et al., 1997; Mathers et al., 1997; Andreazzoli et al., 2003; Casarosa et al., 2003; Matsuda and Cepko, 2004). In the developing hypothalamus, Rax-null mice display thinning of the ventral neuroectoderm (Zhang et al., 2000) and Rax is necessary for the induction of $\mathrm{VMH}$ and ARC identities from embryonic stem cells (Wataya et al., 2008). However, the underlying cellular defects in Rax hypothalamic mutants have not been characterized. Here, we sought to dissect the role of Rax in tuberal hypothalamic development.

\section{Materials and Methods}

Animals and tissue preparation. Animal use was approved by the Animal Welfare Committee of the University of Calgary and the Animal Care and Use Committee at West Virginia University. The following mice (either sex) were genotyped as previously described: Shh::Cre ${ }^{G F P}$ (Jackson Laboratories), Six3::Cre (Guillermo Oliver, St Jude; Furuta et al., 2000), $\operatorname{Rax}^{\text {null }}$ (Zhang et al., 2000), Rax flox (Voronina et al., 2005), Rosa ${ }^{e G F P}$ and Rosa26R (from P.H. Mathers; Jackson Laboratory), Z/AP (Lobe et al., 1999), Sf1 ${ }^{\text {eGFP KI }}$ (Cheung et al., 2012), and Rax::Cre (Swindell et al., 2006). The day of vaginal plugging was defined as E0.5. After death by $\mathrm{CO}_{2}$ asphyxiation, embryos were removed from timed-pregnant CD-1 mice, whereas neonatal [postnatal day $(\mathrm{P}) 0$ ] mouse brains were dissected from newly born pups following euthanasia. All brains were fixed immediately in $4 \%$ paraformaldehyde (PFA) overnight at $4^{\circ} \mathrm{C}$ and equilibrated in $30 \%$ sucrose/PBS overnight. Brains were embedded in Tissue-Tek Optimum Cutting Temperature (O.C.T.) compound (VWR Canada) and cryosectioned (12 $\mu \mathrm{m}$ each; 6-10 sections through the hypothalamus; Leica CM1900).

In situ hybridization and imaging. In situ hybridization was performed as published previously (Kurrasch et al., 2007). Briefly, digoxigenin (DIG)-labeled cRNA riboprobes were generated following the manufacturer's protocol accompanying the DIG-RNA labeling kit (Roche). The probes used for in situ hybridization included Rax (Mathers et al., 1997), Nkx2.1, Sf1, Fezf1 (Kurrasch et al., 2007), Pax6 (Stenman et al., 2003), Shh (Zhang et al., 2001), Tbx3, and Dlx2, Lhxl (kind gifts from Paul Gray, Washington University). DIG-cRNA riboprobes [and FITC-cRNA riboprobes for dual-label in situ hybridization histochemistry] were hybridized to sections at $72^{\circ} \mathrm{C}$ overnight, washed in $0.2 \times \operatorname{SSC}\left(65^{\circ} \mathrm{C}\right)$, and rinsed in TBS. Sections were incubated in a blocking solution and in diluted alkaline phosphatase (AP)-conjugated anti-DIG antibody (1: 5000 ; Roche) overnight at $4^{\circ} \mathrm{C}$, washed with TBS, equilibrated in developing buffer (in $\mu \mathrm{M}$ : 100 Tris, $\mathrm{pH} 9.5,100 \mathrm{NaCl}$, and $50 \mathrm{MgCl}_{2}$ ), and developed in nitroblue-tetrazolium-chloride/5-bromo-4-chlor-indolylphosphate (NBT/BCIP) solution (Roche). After staining, samples were washed with TBS and mounted using Fluoromount G (Sigma-Aldrich). Images were captured with a Zeiss SteREO Lumar V12 light microscope, equipped with a CCD camera (AxioCam HR, Zeiss).

Immunohistochemistry. Embryonic and neonatal brains were removed at the appropriate time point and placed into ice-cold PBS, before fixation (4\% PFA) for $2 \mathrm{~h}$ at room temperature. Brains were washed with PBS and equilibrated in 30\% sucrose/PBS overnight. Brains were embedded in Tissue-Tek O.C.T. compound and cryosectioned ( $20 \mu \mathrm{m}$ each; $6-10$ sections through the hypothalamus; Leica CM1900). Sections were rehydrated using PBS, blocked using 10\% normal donkey serum $2 \mathrm{~h}$ at room temperature, and then exposed to either anti-GFP (Life Technologies), anti-SF1 (Taro Tachibana and Ken Morohashi, Japan), anti-Nkx2.1 (Santa Cruz Antibodies), or anti-Tuj1 (Life Technologies) overnight $\left(4^{\circ} \mathrm{C}\right)$. Slides were washed using PBS and exposed to secondary antibody (anti-rat alexa-546 and anti-rabbit alexa-488; Invitrogen) for $2 \mathrm{~h}$ at room temperature. Images were captured using a Zeiss compound microscope equipped with a monochrome CCD camera (Q-Imaging). Confocal images were captured on Zeiss LSM710 microscope and analyzed using ImageJ (NIH).
Human placental AP staining. Tissue sections were collected from embryonic or neonatal brains generated from Rax::Cre $\times Z / A P$ crosses. Sections were rehydrated with $1 \times$ PBS and then washed in $3 \%$ PBSTriton X100 (Sigma-Aldrich) for $15 \mathrm{~min}$, followed by incubation with $1 \times$ PBS for $1 \mathrm{~h}$ at $65-72^{\circ} \mathrm{C}$. The sections then were washed with buffer solution (100 mm NaCl, 50 mm MgCl2, 100 mm Tris-HCl, pH 9.5), followed by staining with $0.33 \mathrm{mg} / \mathrm{ml} \mathrm{NBT} \mathrm{(Roche)} \mathrm{and} 0.26 \mathrm{mg} / \mathrm{ml} \mathrm{BCIP}$ (Roche) solution or NBT/BCIP (Roche) mixed solution diluted in buffer solution. Rinsing the slides with double-distilled water stopped the reaction, and the dry slides were mounted in Aqua Polymount (Polysciences) and covered with glass coverslips (Fisher Scientific).

$\beta$-Galactosidase staining. Tissue sections were collected from embryonic or neonatal brains generated from Rax::Cre $\times$ Z/AP crosses. After rehydrating the dried tissues, sections were then incubated in X-gal (Roche) working solution ( $5 \mathrm{~mm}$ potassium ferricyanide crystalline, 5 mM potassium ferricyanide trihydrate, $2 \mathrm{mM} \mathrm{MgCl}_{2}$, PBS, $4 \%$ dimethylformamide) at $37^{\circ} \mathrm{C}$ for $12-16 \mathrm{~h}$. Afterward, tissue sections were rinsed in PBS twice for $5 \mathrm{~min}$ and then rinsed in distilled water. Dry slides were mounted in Aqua Polymount (Polysciences) and covered with glass coverslips (Fisher Scientific).

\section{Results}

\section{Rax expression profiles define three early prosencephalic territories}

Rax has been reported to be expressed in both the retinal and hypothalamic primordia (Furukawa et al., 1997; Mathers et al., 1997; Shimogori et al., 2010). To define the dorsoventral and rostrocaudal boundaries of Rax expression in these prosencephalic territories, we compared the distribution of Rax transcripts with Pax6 and Nkx2.1, which label the developing optic stalk and hypothalamus, respectively. Before neurogenesis, on E10.5, Rax transcripts were restricted to distinct dorsal and ventral domains of the prosencephalic neuroepithelium, which give rise to the retina and hypothalamus, respectively (Fig. 1) (Furukawa et al., 1997; Mathers et al., 1997; Shimogori et al., 2010). In particular, Rax expression overlapped with the Pax $6+$ domain in the optic stalk (Fig. 1A) and the Nkx2.1+ domain in the developing hypothalamus (Fig. 1C). A Rax-negative zone divided the two Rax + territories (Fig. 1B, star), parceling this region of the prosencephalon into three distinct domains based on Rax expression profiles.

The hypothalamus is comprised of approximately a dozen nuclei, each with distinct neuronal compositions and precise locations along the rostrocaudal and dorsoventral planes of the forebrain. We reasoned that this complexity may be mirrored by a regionalization of the early prosencephalic neuroepithelium into molecularly distinct territories. To explore whether Rax was expressed in distinct prosencephalic domains along the rostrocaudal axis, adjacent E10.5 coronal sections were examined for the expression of Rax and $N k x 2.1$, the latter labeling the entire ventrocaudal prosencephalon, which is the presumptive hypothalamus (Marín et al., 2002). In serial sections, Rax was expressed in medial-to-caudal domains of the presumptive hypothalamus, but was excluded from the rostral-most $N k \times 2.1+$ hypothalamic territory (Fig. $1 D, E$ ). Together, these studies indicate that Rax is indeed expressed in a distinct region of the presumptive hypothalamic neuroepithelium, the identity of which we explored further below.

\section{Rax is expressed in ARC and VMH progenitors and excluded from DMH progenitors}

Given that Rax expression was limited to the medial-to-caudal extent of the broad $N k \times 2.1+$ hypothalamic neuroepithelium (Fig. 1), we sought to determine whether the anterior Rax+ boundary might correspond to the rostral border of the tuberal 

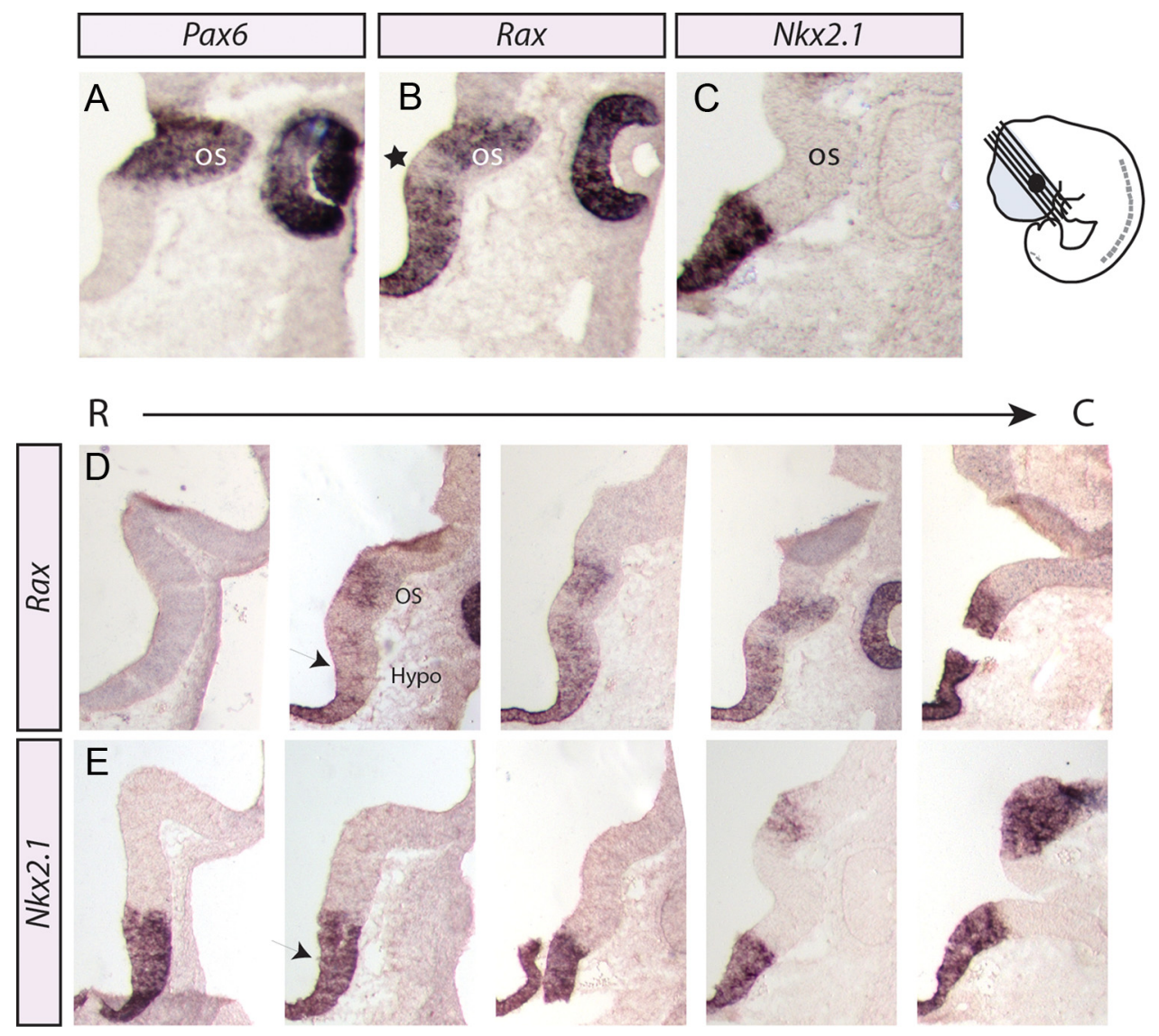

Figure 1. Rax expression in the developing optic stalk and hypothalamus during preneurogenesis. $\boldsymbol{A}-\boldsymbol{E}$, In situ hybridization analysis of coronally sectioned E10.5 mouse brains with Pax $6(\boldsymbol{A})$, Rax $(\boldsymbol{B}, \boldsymbol{D})$, and $N k x 2.1(\boldsymbol{C}, \boldsymbol{E})$ riboprobes. $\boldsymbol{A}$, Pax6 expression in the optic stalk. $\boldsymbol{B}$, Rax expression in the optic stalk and in the developing hypothalamus. A Rax-free region of progenitors between the optic stalk- hypothalamus boundary is noted (star). C, Nkx2.1 expression in the developing hypothalamus. D, E, Coronal rostral-caudal adjacent sections of the developing forebrain show the onset of Rax expression (black arrow) compared with Nkx2.1 expression throughout the ventral prosencephalon. Diagram illustrates the plane of sectioning. OS, optic stalk; Hypo, hypothalamus.

hypothalamus, a medial hypothalamic region. For this purpose, we characterized the expression profile of Rax at midneurogenesis (E12.5), when neural cell fate specification has initiated and the first cell type-specific neurons have been generated. At E12.5, Rax transcripts were restricted to the ventricular zone (VZ) adjacent to the third ventricle $(3 \mathrm{~V})$, where actively dividing progenitors reside (Fig. $2 \mathrm{~A}$ ). Within this region, Rax expression divided the prosencephalic VZ into three distinct dorsoventral domains: I, Rax + (dorsal); II, Rax- (middle); and III, Rax + (ventral; Fig. $2 N)$. To determine whether any or all of these Rax expression domains aligned with tuberal-specific hypothalamic neurons, we first assessed the expression of Nuclear receptor subfamily 5, group A, member 1 (Nr5a1; also known as Steroidogenic factor 1, hereafter referred to as $S f 1$ ), which is specifically expressed in postmitotic neurons of the VMH (Ikeda et al., 2001; Tran et al., 2003). In adjacent E12.5 sections, Rax transcripts in dorsal domain III of the VZ were shown to lie adjacent to $S f 1+$ neurons in the overlying mantle zone (MZ; Fig. 2A,B). Indeed, dual-label in situ hybridization confirmed that Rax expression in the $\mathrm{VZ}$ was adjacent to, but not overlapping with, Sf1 expression in the MZ (Fig. 2C). In addition, Rax expression in the ventral-most aspect of domain III abutted Pomc-labeled neurons, which populate the ARC MZ (Fig. 2D). Combined, these data suggest that Rax expression in domain III VZ progenitors marks the tuberal hypothalamic neuroepithelium, specifically encompassing the VMH and ARC.

We next questioned whether the $\mathrm{DMH}$, which is the third nucleus of the tuberal hypothalamus, also develops in close prox- imity to a Rax + progenitor domain. To test this, we examined the expression profiles of DMH markers Gad67 and Dlx2 (Fig. 2 E, F). Strikingly, Dlx2 expression in DMH progenitors was restricted to the Rax-free zone within prosencephalic domain II (Fig. $2 F$ vs 2A; Fig. 2G). Accordingly, Gad67+ postmitotic neurons in the $\mathrm{DMH} \mathrm{MZ}$ were nestled between the MZs overlying Rax $+\mathrm{VZ}$ domains I and III (Fig. $2 E$ vs $2 A$ ).

Finally, to further define the molecular heterogeneity of the three E12.5 prosencephalic VZ domains defined by the presence or absence of Rax expression, we used additional markers. To start, we asked whether transcription factors known to be involved in ARC/VMH development were expressed in the Rax+ domain III. Indeed, Nkx2.1 (Marín et al., 2002), Six3 (Oliver et al., 1995; VanDunk et al., 2011), Tbx3 (Eriksson and Mignot, 2009), as well as the hypothalamic patterning morphogen Shh (Marín et al., 2002; Szabó et al., 2009b; Shimogori et al., 2010) were all expressed within domain III progenitors (Fig. $2 \mathrm{H}-\mathrm{K}$ ). Six3 expression was markedly lower in domain II than in domain III (Fig. 2I). We also sought to confirm whether Rax expression in domain I marked the hypothalamic sulcus (Kaufman, 1992), a groove along the $3 \mathrm{~V}$ that marks the boundary between the thalamus and hypothalamus and that is labeled by the zinc-finger gene Fezf1 (Hirata et al., 2004; Hirata et al., 2006). We also previously showed Fezf1 to be enriched in postmitotic VMH neurons (Kurrasch et al., 2007). Fezf1 transcripts localized to postmitotic neurons in the $\mathrm{MZ}$ of domain III, as well as in VZ progenitors in domain I (Fig. $2 L$ ). To confirm that the coronal sections analyzed 

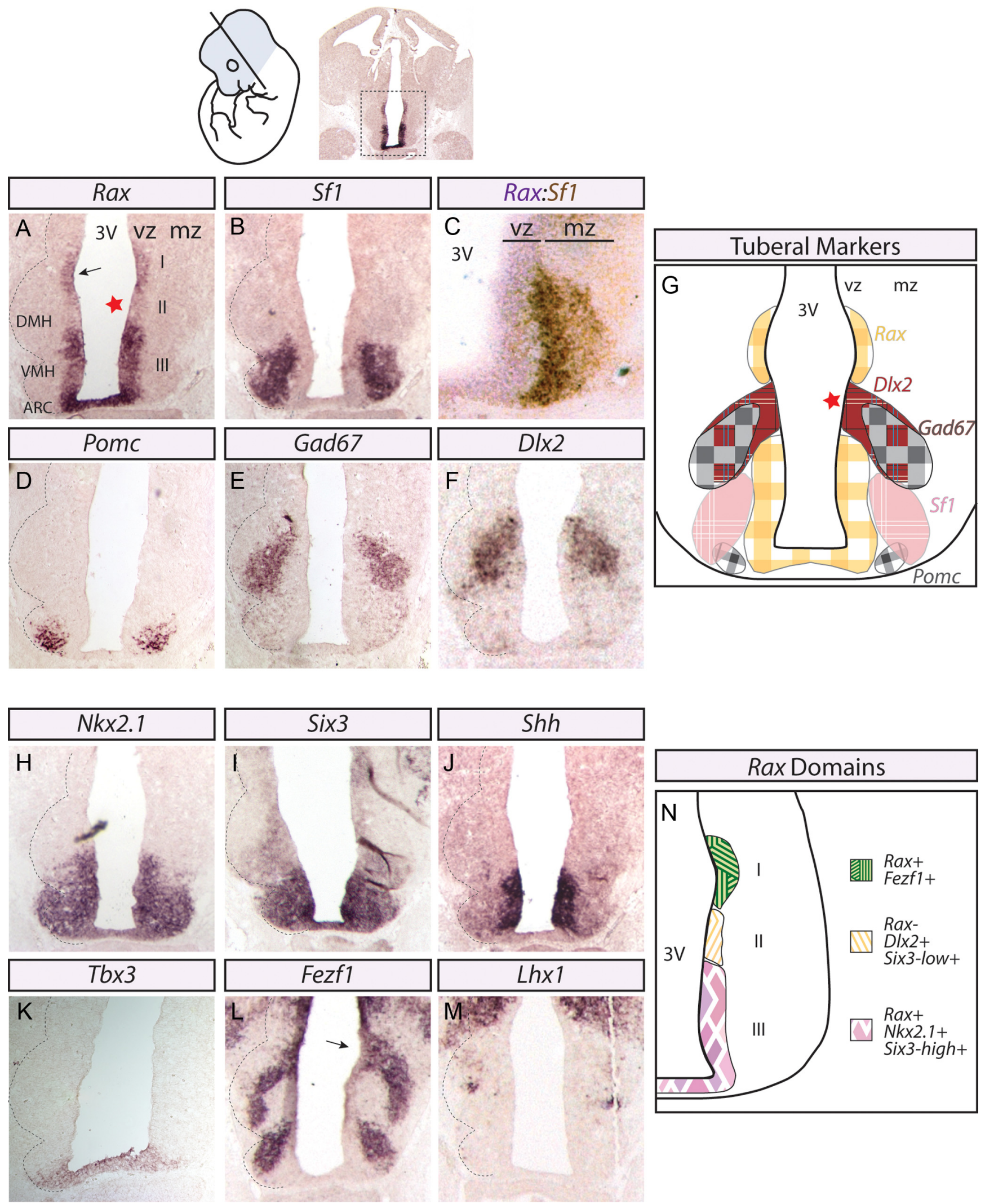

Figure 2. Rax is expressed in ARC-VMH progenitors at mid-neurogenesis. In situ hybridization analyses of coronally sectioned E12.5 mouse brains with hypothalamic markers. Diagram, Top, Left, Section plane. Whole-brain image, Top, Right, Hypothalamic region. $\boldsymbol{A}-\boldsymbol{C}$, Adjacent sections of $\operatorname{Rax}(\boldsymbol{A}), S f-1(\boldsymbol{B})$, and $\operatorname{Rax} / \mathrm{Sf}-1$ dual-label $(\boldsymbol{C})$ riboprobes. The dashed black line denotes the developing tuberal hypothalamic nuclear structures in the mantle zone. Star denotes Rax-free zone. The hypothalamic sulcus is highlighted (black arrow; $A, L)$. Dual-label in situ hybridization for Rax (purple) and Sf- 1 (brown) demonstrates their adjacent but restricted expression profiles to VZ or $M Z$, respectively. $\boldsymbol{D}-\boldsymbol{F}$, In situ hybridization for ARC (D) and DMH $(\boldsymbol{E}, \boldsymbol{F})$ markers. $\boldsymbol{G}$, Diagram representation of images shown in $\boldsymbol{A}, \boldsymbol{B}, \boldsymbol{D}-\boldsymbol{F}$. $\boldsymbol{H}-\boldsymbol{M}$, In situ hybridization for other transcription factors $(\boldsymbol{H}, \boldsymbol{I}, \boldsymbol{K}-\boldsymbol{M})$ and secreted morphogen $(\boldsymbol{J})$ that contribute to ARC-VMH development. $\boldsymbol{N}$, Diagram representation of the three domains defined by Rax expression in the developing tuberal hypothalamic neuroepithelium. 
indeed corresponded to the tuberal hypothalamic region and not a more rostral area, we assayed for expression of $L h x 1$, a marker of the anterior, mammillary, and DMH hypothalamus. The absence of $L h x 1$ expression along the ventral VZ and its expression near the DMH VZ in the plane of section analyzed (Fig. 2M) provided further evidence that we were indeed assaying the tuberal hypothalamic region.

In summary, we have defined three molecularly distinct dorsoventral progenitor domains within the E12.5 prosencephalon, including: (1) Rax +/Fezf1+ domain I progenitors, which mark the prospective hypothalamic sulcus; (2) Rax-/Dlx2+/Six3-low expression+ domain II progenitors, which are adjacent to the presumptive DMH of the tuberal hypothalamus; and (3) Rax+/ Nkx2.1+/Six3-high expression + domain III progenitors, which align with VMH and ARC nuclei (Fig. $2 N$ ).

\section{Rax is expressed in tuberal and mammillary neuronal progenitors}

Thus far our data indicated that prosencephalic progenitors are heterogeneous along the dorsoventral plane, but we reasoned that additional complexity might also be observed in the rostrocaudal plane. Specifically we asked (1) whether dorsoventral domains I-III retained their distinct Rax expression profiles across the entire rostrocaudal axis and (2) whether, in addition to the tuberal hypothalamic region, Rax was also expressed in neighboring hypothalamic regions, namely rostrally, the anterior hypothalamus, and/or caudally, the mammillary nucleus. To address these questions, we examined gene expression in a complete rostral-to-caudal series of coronal E12.5 sections. Serial analyses were necessary because individual prosencephalic nuclei have complex threedimensional architectures such that their geometric parameters (i.e., width, length, shape, overall area) can vary widely depending on the plane of section. In serial sections beginning at the anterior hypothalamus (Fig. 3, column 1) and ending at the mammillary nucleus (Fig. 3 , columns 6 and 7), we defined four distinct domains based on the expression of Rax and other markers:

1. Anterior hypothalamus. Rax was not expressed in the anterior-most E12.5 sections (as shown at E10.5), whereas Sf1, Fezf1, Dlx2, Lhx1, Nkx2.1, and Six3 were expressed in these rostral sections through the hypothalamus (Fig. 3, column 1). Note that the absence of Rax expression in the anterior hypothalamus is in contrast to previous reports of a Rax + domain in this region of the embryonic brain (Shimogori et al., 2010). In addition, detection of $S f 1$ transcripts in this rostral region suggests that $S f 1$ might be expressed outside the VMH.

2. Rostral tuberal hypothalamus. In slightly more intermediate sections (Fig. 3, columns 2 and 3; black box), Rax was expressed in two distinct domains located along the dorsoventral axis and separated by a Rax-free zone, as outlined above. Domain III Rax+ progenitors abutted $S f 1+$ and Fezf1+ neurons in the VMH (and ARC; see Fig. 2). Domain II Rax - progenitors expressed the DMH marker Dlx2, and lay adjacent to $L h x 1+$ neurons in the overlying MZ. Finally, domain I Rax+ progenitors coexpressed Fezfl, but fell outside the presumptive tuberal hypothalamus and at the hypothalamic-thalamic boundary.

3. Caudal tuberal hypothalamus. In sections delineating the caudal half of the tuberal hypothalamus (Fig. 3, columns 4 and 5), Rax was continuously expressed throughout the ventral $\mathrm{VZ}$ and in the infundibular region of developing prosencephalon (column 5, black arrow).
4. Mammillary hypothalamus. In sections representing the caudal-most region of the hypothalamus (Fig. 3, columns 6 and 7), Rax expression becomes progressively more limited to ventral-most domains (Fig. 3, column 7) with the posterior Rax expression domain in the ventral prosencephalon corresponding to mammillary progenitors of the caudal hypothalamus, which also express Six3 and Nkx2.1 (Fig. 3, columns 6 and 7).

Together, our serial analyses reveal that Rax is dynamically expressed along the dorsoventral and rostrocaudal axes of the prosencephalon. Furthermore, they allow us to conclude that Rax expression is excluded from the anterior hypothalamus, while Rax transcripts are detected in progenitors in the vicinity of the tuberal and mammillary hypothalamus.

\section{Rax + progenitors give rise to ARC and VMH neurons}

We determined above that Rax is expressed in domain III prosencephalic progenitors that lie adjacent to developing ARC and VMH nuclei, whereas the DMH is abutted by a Rax-free progenitor zone. However, expression is not lineage, so to make more definitive statements regarding the progeny of Rax-expressing prosencephalic progenitors, we performed Cre-based lineage tracing. To identify cells derived from Rax-expressing progenitors, we used a Rax::Cre driver that was generated using 5' upstream regulatory sequences of the medaka fish Rax ortholog (Swindell et al., 2006). Rax::Cre mice were crossed with the Rosa26R-flox-stop-flox- $\beta$-gal (Rosa26R; Fig. 4) reporter line. From these crosses, $\beta$-galactosidase ( $\beta$-gal) is expressed in Rax + lineages where Cre promotes recombination. We thus asked whether $\beta$-gal + cells were localized within ARC and/or $\mathrm{VMH}$ nuclear territories, as demarcated by $\alpha-\mathrm{Nkx} 2.1$, which labels both nuclei, and $\alpha$-SF1, which labels the VMH. In adjacent sections of P0 Rosa26R $\times$ Rax:: Cre brains, $\beta$-gal + cells were located within the Nkx2.1+ ARC and SF1+ VMH territories (Fig. 4A-C). To confirm that neurons derived from Rax + lineages were indeed of a VMH identity, we performed double immunofluorescence for $\beta$-gal and SF1, identifying $\beta$-gal+/SF1+ neurons (Fig. $4 D-F$ ). Notably, not all $\beta$-gal + neurons were labeled by SF1, suggesting that Rax-expressing progenitors may only give rise to a subset of VMH neurons. However, the extent to which Rax+ progenitors contributed to the VMH neuronal pool could not be definitively determined for technical reasons: (1) Rax::Cre mice were derived using medaka regulatory elements and may be lacking promoter/ enhancers that are required to recapitulate the full profile of Rax expression in tuberal progenitors, and (2) the Rax::Cre transgene may have inserted a region of the genome where Cre expression is mosaic, resulting in inefficient recombination. Regardless of these limitations, we can conclude that at least a subset of VMH and ARC neurons are derived from Rax + lineages, in support of our expression analyses.

\section{Molecular mapping of brain regions innervated by Rax-expressing cells}

$\mathrm{VMH}$ and ARC projections are thought to undergo pathfinding during the postnatal period (Bouret et al., 2004a,b), but we (Cheung et al., 2012) and others (Shimamura et al., 1995) have observed axonal fibers in the tuberal hypothalamus much earlier in development-in the early neurogenic period. To ascertain whether Rax+ lineages contribute to these early-born hypothalamic circuits, and to define the brain regions innervated by Rax daughter cells, we used Rax::Cre in combination with the dual reporter line, Z/AP (Lobe et al., 1999). Z/AP transgenic mice 


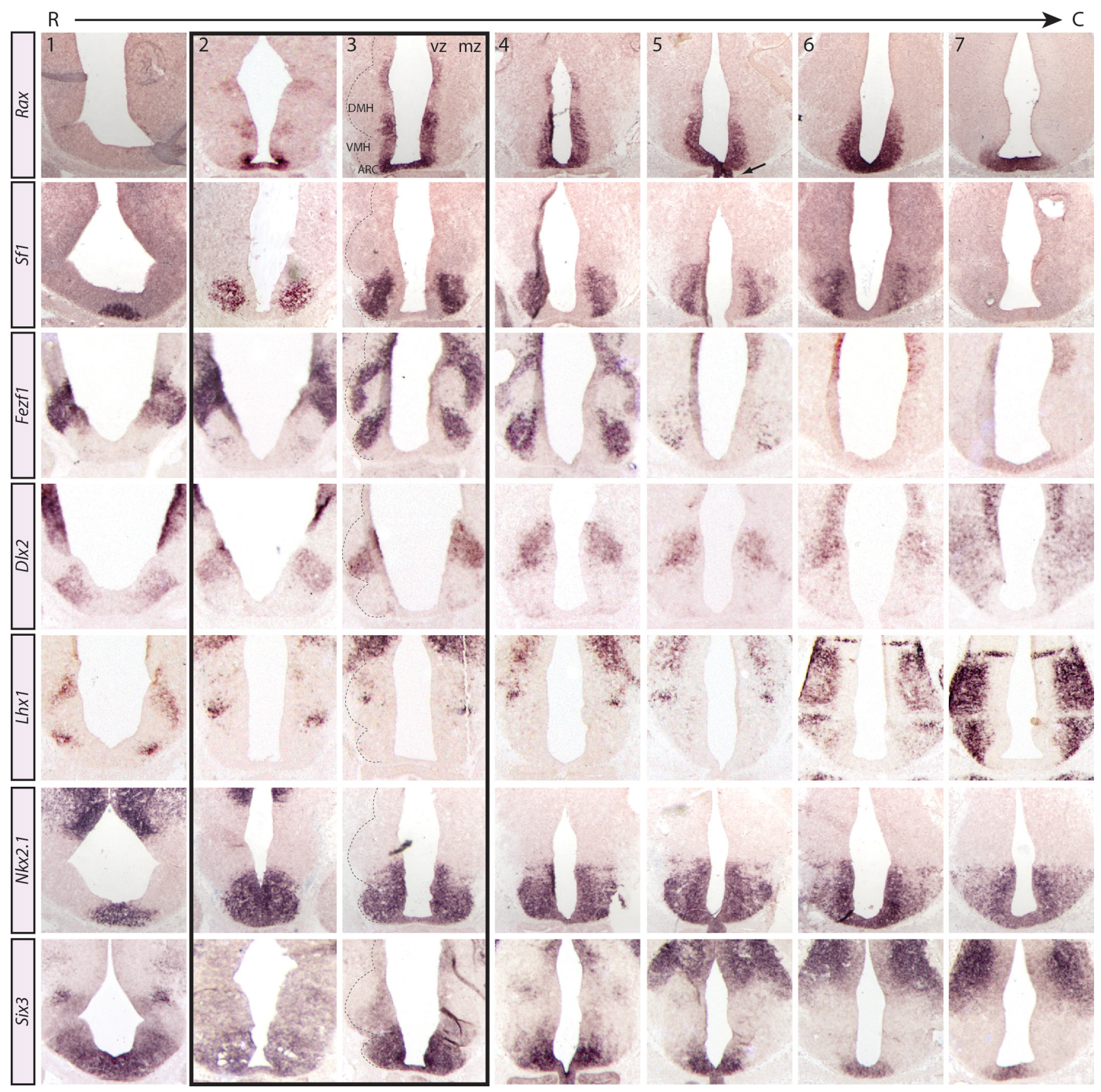

Figure 3. Rax expression boundaries relative to other hypothalamic markers in serial sections from the anterior through the mammillary hypothalamic regions. In situ hybridization analyses of coronally sectioned E12.5 mouse brains probed with several hypothalamic markers. The dashed black line denotes the developing nuclear structures in the mantle zone. Black box outlines the onset of the tuberal hypothalamic region (rostral tuberal hypothalamus). Numbers on the top row refer to the column.

ubiquitously express LacZ before Cre-mediated excision, while the human placental alkaline phosphatase (hPLAP) reporter is turned on postexcision (Fig. 5). This excision-dependent switch of reporter genes allows a precise and accurate assessment of Cre activity. Additionally, because hPLAP is a GPI-linked enzyme that localizes to the plasma membrane (Fields-Berry et al., 1992; Wong and Low, 1994), it has been shown to preferentially accumulate in axons and dendrites and not cell bodies in neurons (Badea and Nathans, 2004). To test the efficiency of Rax::Cre-mediated excision with the Z/AP reporter strain, we first analyzed $\beta$-gal and AP enzymatic activities in P0 Cre- and $\mathrm{Cre}+$ pups. As expected, $\beta$-gal activity was reduced in the presumptive $\mathrm{VMH}$ in P0 Rax::Cre+;Z/AP+ neonates compared with Rax::Cre-;Z/AP controls (Fig. $5 B$ vs $5 A$ ). Poor expression of the Z/AP transgene in the ARC precluded detailed tracing of ARC Rax + lineages (Fig. 5A). In addition, high AP activity was detected in the axons and dendrites that surround the VMH core in P0 Rax::Cre+;Z/AP+ animals relative to controls (Fig. 5C,D). In contrast, $\mathrm{AP}+$ cell bodies were not detected in the $\mathrm{VMH}$ itself, consistent with the idea that AP is preferentially transported to axons and dendrites. We thus conclude that the $Z / A P$ reporter can be used to trace the axonal projections of $\mathrm{VMH}$ neurons derived from the Rax + lineage.

To ask whether Rax + neuronal lineages extended projections during the early neurogenic period, we examined E12.5 Rax::Cre+; $Z / A P+$ embryos, revealing high AP activity in projec- 

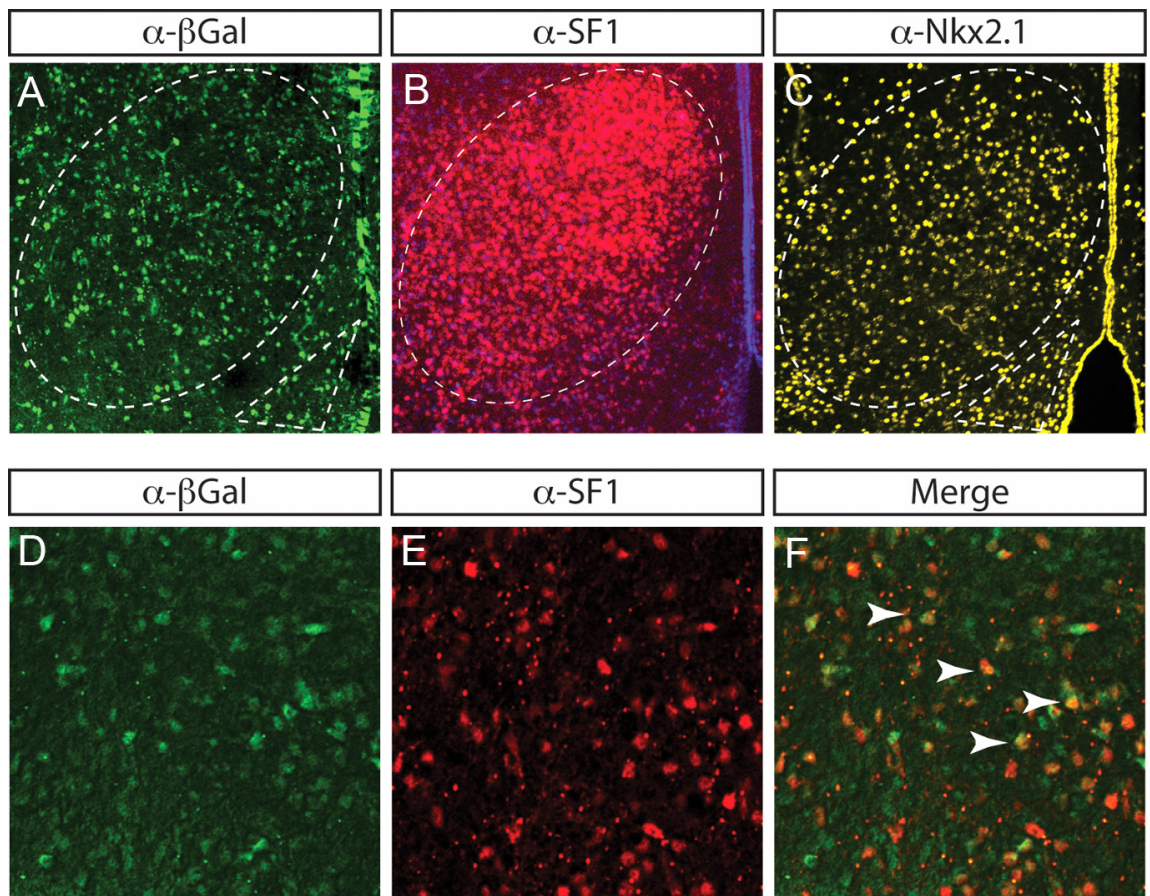

Figure 4. Rax-expressing progenitors give rise to VMH neurons. Immunofluorescence analyses of sectioned P0 brains with $\alpha$ - $\beta$ gal, $\alpha$-SF1, and $\alpha$-Nkx2.1 is shown. The VMH (dotted oval) and ARC (dotted triangle) are highlighted. $\boldsymbol{D}-\boldsymbol{F}$, Double immunofluorescence of $\beta$-gal $(\boldsymbol{D})$, SF1 $(\boldsymbol{E})$, and merged $(\boldsymbol{F})$ on P0 Rax::Crex Rosa26R brains. Dual-labeled Rax + lineages and SF1 + neurons are noted (yellow cells, white arrowheads).

tions lining the lateral hypothalamic wall (Fig. 5E, red arrow). In addition, while domain III VZ progenitors were for the most part devoid of AP activity (Fig. 5E, dashed oval), a small number of radially oriented AP+ cells were evident in the VZ (Fig. 5E, arrowhead). The most likely identity of these AP+ VZ cells are radial glial progenitors that have not yet differentiated into neurons, in which case the AP is kept within the soma as progenitors do not extend projections. To test whether AP labeling in the lateral hypothalamic wall of E12.5 Rax::Cre +; Z/AP+ embryos corresponded to VMH axonal projections, adjacent sections were labeled with antibodies to the neuronal class III $\beta$-tubulin ( $\alpha$-Tuj1), which labels axons (Lee et al., 1990), and Nkx2.1, which will label ARC-VMH nuclei (Fig. 5F-H). Anti-Tuj1 immunolabeling marked axons emanating from the Nkx2.1+ VMH/ARC territory (Fig. $5 H$ ), recapitulating the AP staining pattern (Fig. 5E). We can thus conclude that Rax+ lineages in the VMH undergo axon pathfinding as early as E12.5, much earlier than previously appreciated.

Finally, to characterize the brain regions innervated by Rax+ neuronal lineages in the neonate, P0 Rax::Cre;Z/AP mice were assayed for AP activity in three rostrocaudal hypothalamic regions: the anterior, tuberal, and mammillary (Fig. 5L). Within the anterior hypothalamus, AP stained projections were detected in the globus pallidus (GP), lateral hypothalamic area (LHA), and amygdala (Fig. 5I). All of these areas are known to receive VMH projections (Canteras et al., 1994). Within the tuberal hypothalamic plane, $\mathrm{AP}+$ processes were observed to extend toward the bed nucleus of the stria terminalis (BST) and to innervate the amygdala, GP, and LHA (Fig. 5J), which are also known targets of VMH neurons (Canteras et al., 1994). In addition, within the plane of the tuberal hypothalamus, intrahypothalamic microcircuits known to connect the tuberal hypothalamic nuclei (Canteras et al., 1994; Thompson and Swanson, 1998; Elias et al., 1999) arose from Rax + progenitors (Fig. 5J, micro). Finally, in the plane of the mammillary hypothalamus, $\mathrm{AP}+$ processes derived from Rax + neurons were shown to innervate caudal brain regions, including the rostral substantia nigra, caudate-putamen (CP), and ventral tegmental area (Fig. $5 K$ ), also known targets of the VMH/ARC (Saper et al., 1979).

Given that Rax is expressed in progenitors that give rise to other forebrain and retinal structures, as well as both tuberal and mammillary nuclei, we sought to confirm the origins of the $\mathrm{AP}+$ projections to be $\mathrm{VMH}$. To do so, we relied on our $S f 1^{e G F P \mathrm{KI}}$ mouse model, which expresses GFP distinctly in SF1 cell bodies and projections (Cheung et al., 2012). If AP staining was instead arising from retinal or mammillary origins, for example, we reasoned that $\mathrm{AP}+$ projections in P0 Rax::Cre;Z/AP brains would not display the same projection profiles as the GFP+ processes in P0 SfI $1^{\text {eGFPKI }}$ brains. In P0 Sf1 $1^{\text {eGFPKI }}$ brains, GFP+ lineages were detected in precisely the same regions as AP staining revealed, including the amygdala (Fig. 5M, A) and globus pallidus (Fig. $5 N, \mathrm{GP}$ ) in anterior sections, projections to the BST (Fig. 5P) and intrahypothalamic microcircuits (Fig. 5O) in the plane of the tuberal hypothalamus, and the substantia nigra and caudate-putamen (Fig. 5Q, SP and CP) in the plane of the mammillary hypothalamus. We thus conclude that neurons derived from Rax lineages display a pattern of connectivity that is consistent with their identity as tuberal hypothalamic neurons, providing further validation that Rax-expressing progenitors do indeed give rise to neurons with a VMH identity.

\section{Rax is required for ARC-VMH neuronal identities}

The expression of Rax in VMH-ARC progenitors during early and midneurogenesis (Figs. 1-5) suggested a possible role for this homeobox gene in conferring regional and/or subtype-specific identities to progenitors and their neuronal progeny. Previous analyses of Rax-null embryos reported a thinning of the ventral neuroectoderm, but whether this correlated with the loss of specific neuronal populations was not addressed (Zhang et al., 2000). To examine the functions of Rax in early stages of ARCVMH development, we used a conditional approach, using both Rax-null mice (Zhang et al., 2000) and mice carrying a Rax flox conditional mutant allele (Voronina et al., 2005). Rax flox/null mice were crossed with a Six3::Cre transgenic mouse strain (Furuta et al., 2000) to conditionally inactivate Rax [conditional knock-outs (CKOs)] in the developing brain. Note that we demonstrated above that Six 3 is coexpressed with Rax in domain III tuberal hypothalamic progenitors at E12.5 (Figs. 2, 3), and in situ hybridization on adjacent sections showed that Rax and Six 3 expression even more broadly overlaps in the E10.5 prosencephalon (Fig. $6 A, B)$. Moreover, Six3::Cre transgenics have been shown to promote Cre-mediated recombination in the developing optic cup, optic stalk, and ventral hypothalamus starting $\sim$ E9.0-E9.5 (Furuta et al., 2000), a time point that coincides with patterning of the hypothalamic primordium. Accordingly, a reporter cross of Six3::Cre $\times$ Rosa $^{e G F P}$ reveals broad Cre activity within the VMH and ARC in neonatal brains (Fig. $6 \mathrm{C}$ ). Combined, the overlap- 

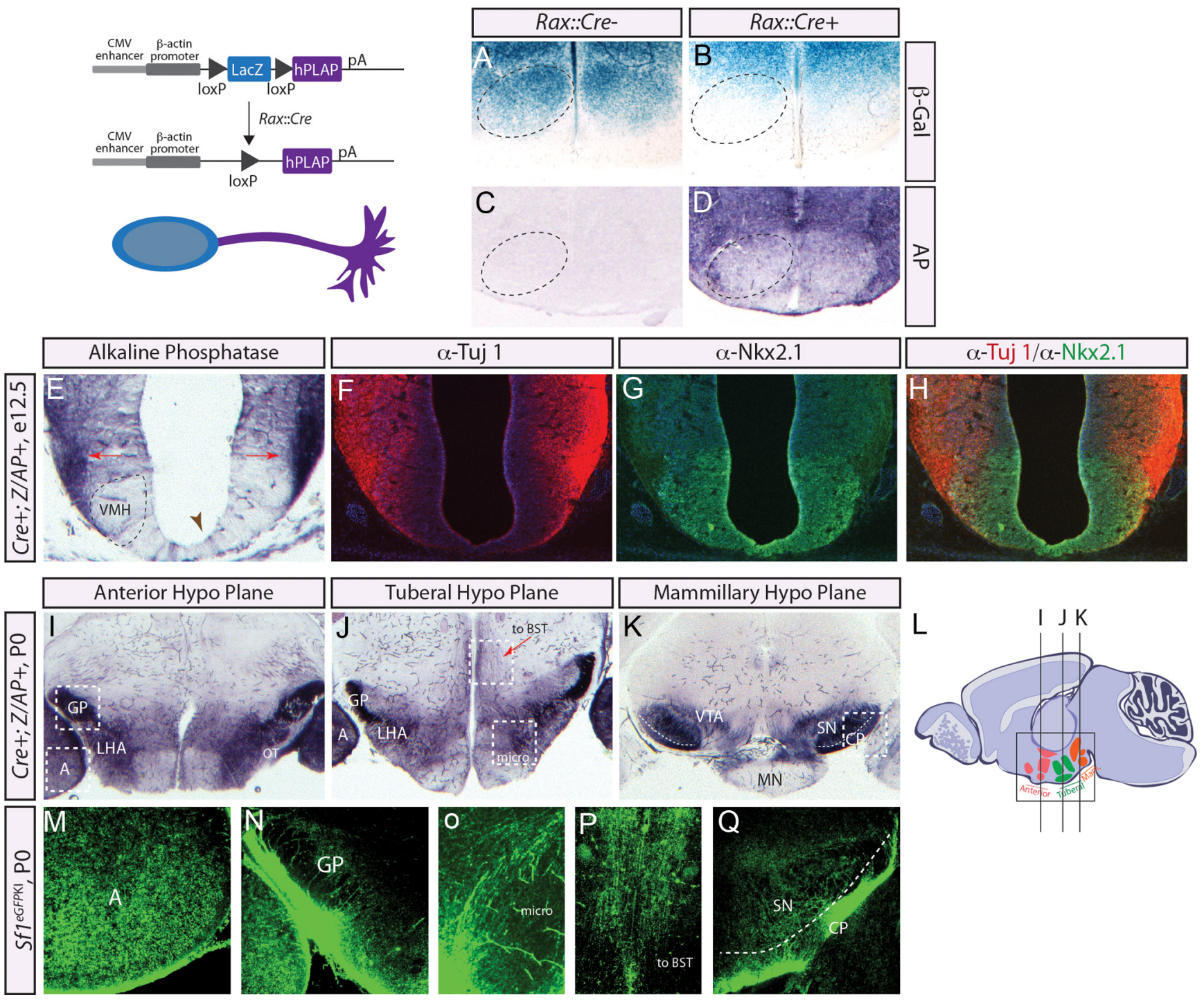

Figure 5. Molecular mapping of Rax-expressing lineages. Schema illustrates the genetic cross and the compartmentalization of $\beta$-gal staining in the soma and AP staining in the projections. Here for illustrative purposes, we show $\beta$-gal staining and AP staining within the cell, but this double staining would not occur in vivo. $A-D, \beta$-Gal and AP staining on neonatal brains for Rax::Cre-and Rax:: Cre + animals crossed with Z/AP. Dashed oval marks the VMH.E, AP staining on E12.5 brains generated crossing Rax::Cre $\times Z / A P$. The developing VMH nucleus consisting of the cell bodies (black dashed oval) and the axonal projections (red arrows) are noted. Clonal populations of Rax + cells are highlighted (brown arrowhead). $\boldsymbol{F}$-H, Double-label immunofluorescence of Tuj 1 and Nkx2.1 of E12.5 Rax::Cre $\times$ Z/AP brains. Merged image illustrates the proximity of Nkx2.1 + cell bodies and Tuj1 + projections. I-K, AP-stained projections generated using Rax::Cre $\times$ Z/AP are shown for the anterior, tuberal, and mammillary hypothalamic regions. $\boldsymbol{L}$, Diagram showing locations of planes shown in $\mathbf{I}-\boldsymbol{K}$. White boxes denote regions highlighted in $\boldsymbol{M - Q} . \boldsymbol{M} \mathbf{Q}, \mathbf{I m m u n o f l u o r e s c e n c e ~ o f ~}$ GFP-labeled VMH projections in neonatal brains from Sf7 ${ }^{\text {eGFPKI }}$ animals. A, amygdala; $0 \mathrm{OT}$, optic tract; micro, microcircuits; VTA, ventral tegmental area; $\mathrm{SN}$, substantia nigra; $\mathrm{MN}$, mammillary nucleus.

ping expression data and the Six3::Cre lineage trace suggest that this driver would promote broad deletion of Rax throughout the ventral hypothalamus early in development.

To examine the effects of eliminating Rax on cell fate specification in the tuberal hypothalamus, we analyzed conditional Rax mutants (Six3::Cre;Rax flox/null) and control littermates (Six3::Cre; Rax ${ }^{f l o x /+}$ ), which were phenotypically wild type. Strikingly, in P0 Six 3::Cre;Rax flox/null CKO brains, the expression of Fezf1, Nkx2.1, and Pomc was lost or strongly diminished in the tuberal hypothalamus, suggesting that neurons with $\mathrm{VMH}$ and ARC cellular identities are for the most part not generated in the absence of Rax (Fig. $6 D-I$ ). To determine whether any cellular identities of the tuberal hypothalamus were maintained, we assayed for Gad67 expression, a marker for DMH neurons, which should arise from Rax- progenitors. Notably, in wild-type brains some Gad67 expression is detected in ARC neurons at P0, but GABAergic neurons expressing this biosynthetic enzyme are excluded from the VMH (McClellan et al., 2006). We found that Gad67 expression was widespread throughout the tuberal hypothalamus in P0 Six3::Cre; Rax flox/null CKO embryos, including in the presumptive $\mathrm{VMH}$, which is a Gad67-negative territory in littermate controls (Fig. 6J,K). The apparent expansion of the Gad67 expression territory into the VMH in conditional Rax mutants (Fig. $6 \mathrm{~K}$, bracket) suggested that $\mathrm{VMH}$ neurons may not be lost, but rather respecified in the absence of Rax function. This Six3::Cre driver displayed variability in our hands, so although a global loss of VMH and ARC neurons in Rax mutants generated with this driver is not certain, we can conclude that Rax is required to specify some ARC and VMH neuronal identities.

\section{Contribution of Rax + progenitors to VMH neurons is dependent on Rax function}

To address the possibility that Rax is required for tuberal hypothalamic progenitor specification, we sought a different Cre line 

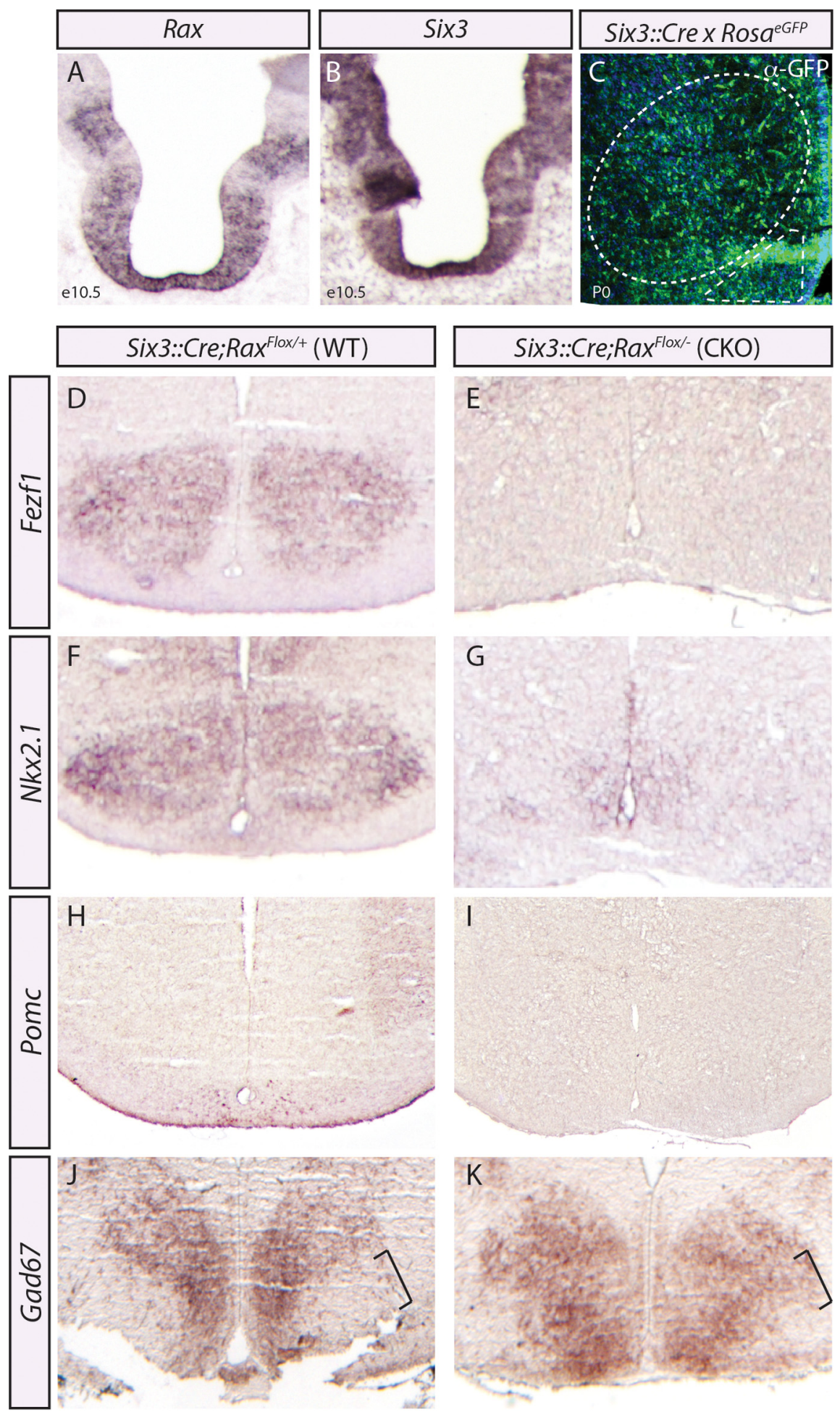

Figure 6. Rax is required for ventral hypothalamic lineages. $A, B$, In situ hybridization analysis of adjacent coronally sectioned E10.5 brains with Rax and Six3 riboprobes. C, Anti-GFP labeling of Six3::Cre lineages and neuronal cell bodies (DAPI, blue) in the neonatal brain. The VMH (dotted oval) and ARC (dotted triangle) are highlighted. $\boldsymbol{D}-\boldsymbol{K}$, In situ hybridization using Fezf1 $(\boldsymbol{D}, \boldsymbol{E})$, Nkx2.1 $(\boldsymbol{F}, \boldsymbol{G})$, Pomc $(\boldsymbol{H}, \boldsymbol{I})$, and Gad67 $(\boldsymbol{J}, \boldsymbol{K})$ riboprobes on Rax neonatal (P0) controls $(\boldsymbol{D}, \boldsymbol{F}, \boldsymbol{H}, \boldsymbol{J})$ and conditional mutants $(\boldsymbol{E}, \boldsymbol{G}, \boldsymbol{I}$, $\boldsymbol{K})$ generated using Six3:: (re. The expansion of Gad67 into VMH territory is noted (J, $\boldsymbol{K}$, black brackets).

that would eliminate Rax in a more limited subset of ARC-VMH progenitors. Specifically, we used a $S h h:: C r e^{G F P}$ driver (Harfe et al., 2004) to conditionally inactivate Rax in a subset of presumptive VMH progenitors in Rax flox/null mice (Voronina et al., 2005). In adjacent E10.5 sections, Shh was expressed in a medial stripe in the center of the Rax + progenitor zone (Fig. $7 A-D$ ), presumably corresponding to $\mathrm{VMH}$ progenitors, as has been shown previously (Szabó et al., 2009a; Shimogori et al., 2010; VanDunk et al., 2011). Shh::Cre ${ }^{G F P}$ mice express Cre recombinase in the developing prosencephalon beginning $\sim$ E10 (P.H. Mathers, unpublished data). To monitor Cre expression in Shh::Cre ${ }^{G F P}$ embryos, we took advantage of its fusion to GFP. In E12.5 Shh::Cre $e^{\text {GFP }}$ hypothalami, GFP + cells were detected within the VZ overlying the $S f 1+\mathrm{VMH}$ MZ (Fig. $7 E, F$ ). At E17.5, postneurogenesis, mosaic GFP expression was observed within the VMH/ARC nuclei outlined by Nkx2.1 expression (Fig. 7G,H), with preferential GFP expression in the presumptive $\mathrm{VMH}$ and not the ARC (Fig. $7 \mathrm{H}$, red arrow). We thus conclude that the Shh::Cre ${ }^{G F P}$ driver should eliminate Rax primarily in $\mathrm{VMH}$ progenitors, allowing us to study the behavior of Rax flox/null $\mathrm{mu}$ tant cells in a milieu of WT tuberal hypothalamic cells.

To generate Rax CKOs, Shh::Cre $e^{G F P}$ and Rax ${ }^{f l o x / n u l l}$ mice were intercrossed, and Shh::Cre ${ }^{G F P} ; \operatorname{Rax} x^{\text {flox/null }} \mathrm{CKO}$ and Shh::Cre ${ }^{G F P} ; R a x^{f l o x /+}$ wild-type control embryos were collected. First, we examined whether Rax inactivation affected the expression of $S f 1$, as a definitive VMH marker. Strikingly, the elimination of Rax in $\mathrm{VMH}$ progenitors in CKO embryos led to the loss of a central stripe of $S f 1+$ neurons in the presumptive VMH at E12.5, E13.5, and E14.5 compared with WT controls (Fig. 7I-P, brackets). We also examined the expression of $N k \times 2.1$, which broadly marks ventral hypothalamic regions, from the rostral anterior hypothalamus through to the mammillary hypothalamus, as well as the VMH and ARC (Fig. 3). In Rax CKOs, Nkx2.1 expression was maintained in the anterior (Fig. $7 Q, U$ ) and mammillary (Fig. 7T,X) hypothalamus but was void from a band of postmitotic neurons in the tuberal hypothalamic region (Fig. $7 R, S, V, W$ ). Combined, these data support the idea that Rax is uniquely required for $\mathrm{VMH}$ cell specification.

We next probed the identity of the Sf1-/Nkx2.1 - cells. We relied upon neonatal mutant brains for these studies because hypothalamic nuclei formation is complete by this stage. For this purpose, P0 Rax CKO brains were assayed for the expression of additional VMH (Fezf1, Nkx2.1, VGlut2) and nonVMH markers, including Gad67, which is expressed in the DMH and other hypothalamic regions, and Pomc, which labels the ARC. In P0 Rax CKO hypothalami, a similar central stripe of cells failed to adopt a VMH identity, as assessed by the expression of 

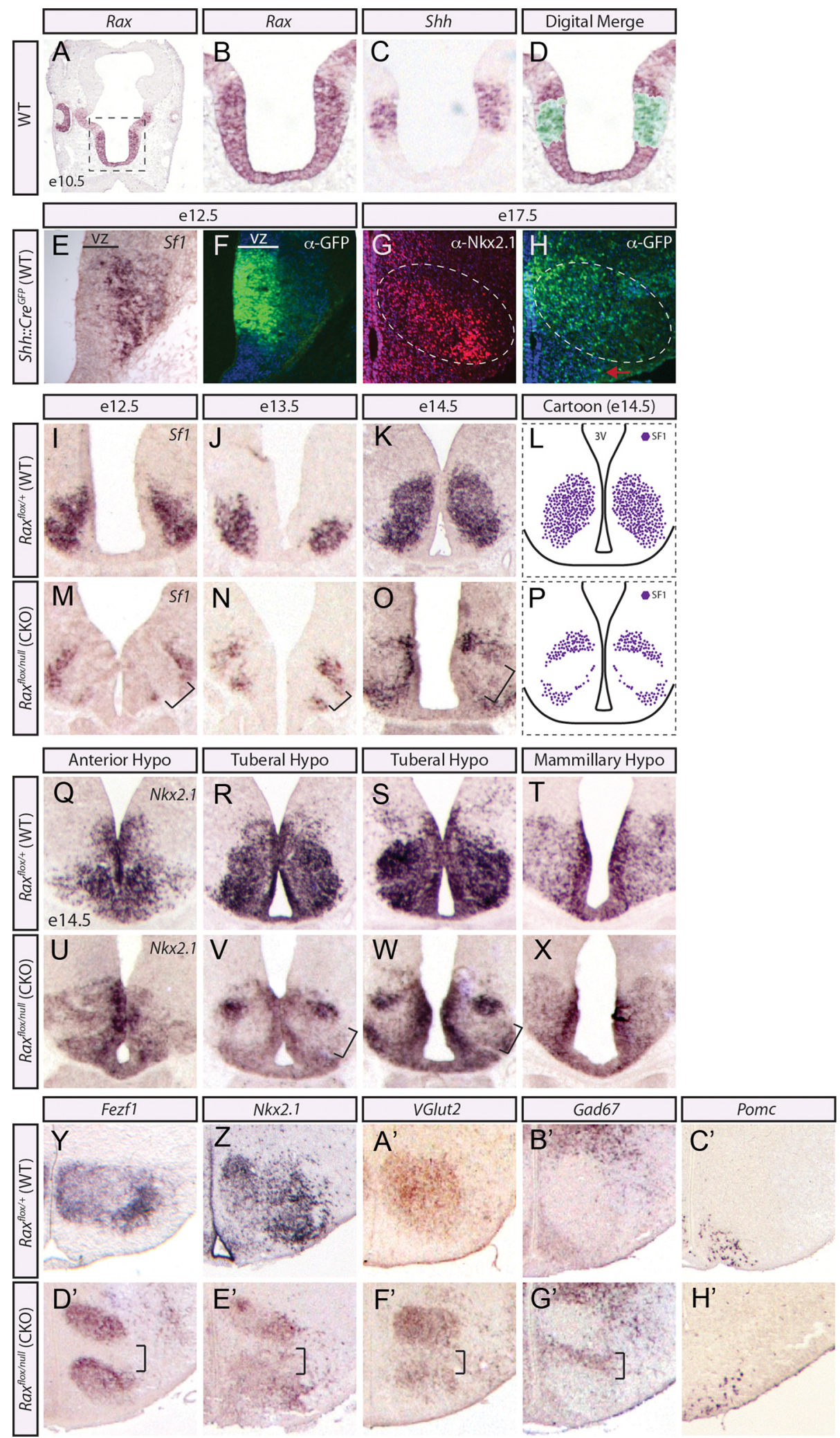

Figure 7. Loss of Rax results in abnormal VMH nuclei formation. $A-D$, In situ hybridization analyses of adjacent coronally sectioned E10.5 brains with Rax and Shh. $A$, Whole-brain image denotes the area of interest. $\boldsymbol{D}$, Digitally merged image shows the overlap of Rax and Shh expression domains at E10.5. $\boldsymbol{E}, \boldsymbol{F}$, In situ hybridization using Sf1 riboprobe and immunofluorescence for GFP in adjacent coronal sections of Shh:: Cre ${ }^{G F P}$ at E12.5. G, $\boldsymbol{H}$, Immunofluorescence for Nkx2.1 and GFP in adjacent coronal sections of Shh::(re ${ }^{G F P}$ at E17.5. (re expression in the ARC (red arrow) is highlighted. Dotted oval denotes VMH. I-P, In situ hybridization using Sf1 riboprobe across neurogenesis, E12.5 $(\boldsymbol{I}, \boldsymbol{M}), \mathrm{E} 13.5(\boldsymbol{J}, \mathbf{N})$, and E14.5 $(\boldsymbol{K}, \mathbf{0})$, in Rax CKO mutants and WT controls generated by crossing Shh::Cre ${ }^{G F P} ;$ Rax $^{+/ \text {null }} \times$ Rax $^{\text {floxed/floxed }}$. The void of $S f 1+$ cells in the central region of the VMH is noted $(\boldsymbol{L}, \boldsymbol{P}$, black brackets and diagram). $\mathbf{Q}-\boldsymbol{X}, I n$ situ hybridization using the broad ventral hypothalamic marker Nkx2.1 is shown for both WT and Rax CKO generated as per above across the three hypothalamic regions in adjacent coronal sections at E14.5. The Nkx2.1-free region with the tuberal hypothalamus is noted $\left(\boldsymbol{V}, \boldsymbol{W}\right.$, black brackets). $\boldsymbol{Y}-\boldsymbol{H}^{\prime}$, In situ hybridization analyses of WT $\left(\boldsymbol{Y}-\boldsymbol{C}^{\prime}\right)$ and $\operatorname{Rax} C \mathrm{CKO}\left(\boldsymbol{D}^{\prime}-\boldsymbol{H}^{\prime}\right)$ neonatal brains generated as per above. A region void of VMH markers in Rax CKO ( $\boldsymbol{D}^{\prime}-\boldsymbol{F}^{\prime}$, black brackets) and a region with misexpression of non-VMH markers (Gad67; $\boldsymbol{G}^{\prime}$, black brackets) are noted. ARC-specific riboprobe is also shown (Pomc, $\left.\boldsymbol{C}^{\prime}, \boldsymbol{H}^{\prime}\right)$. 

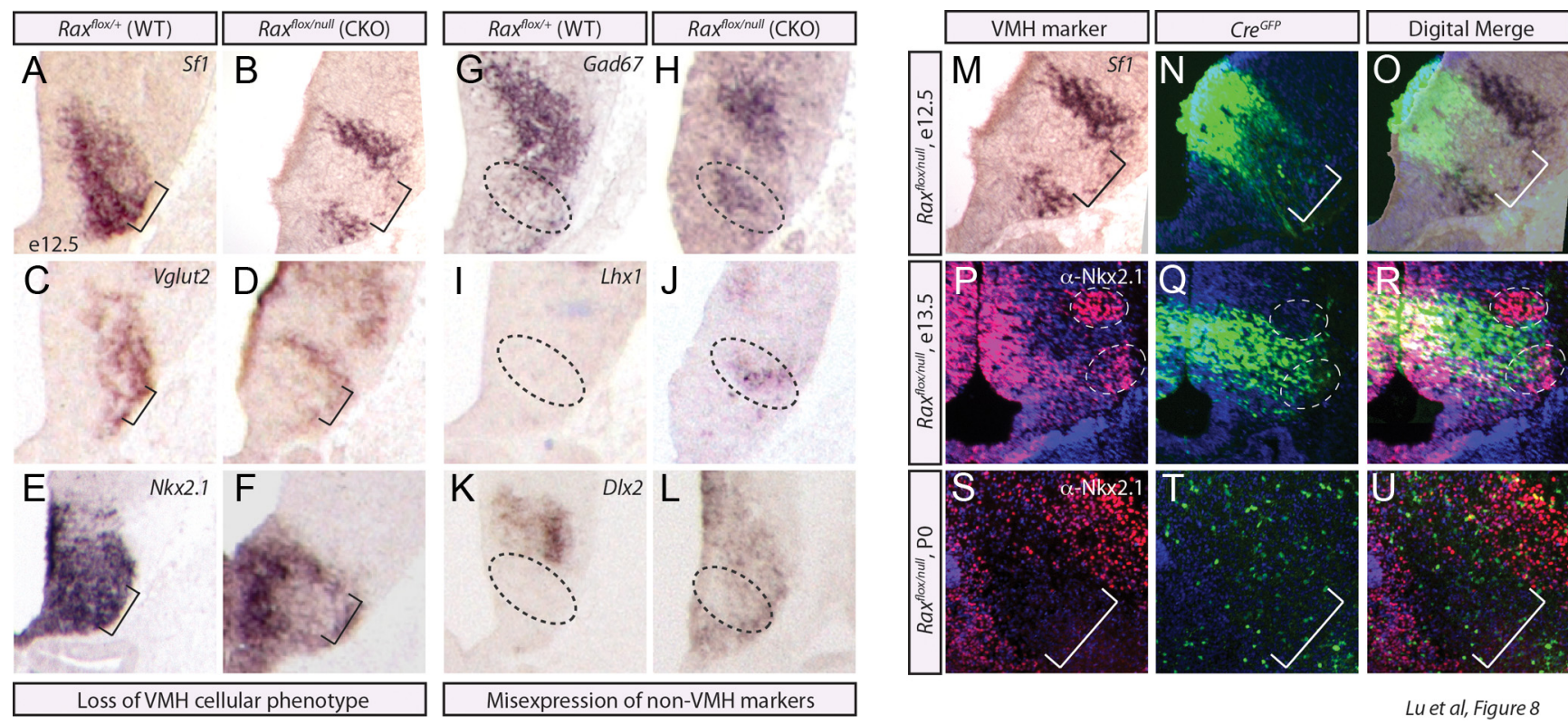

Lu et al, Figure 8

Figure 8. Elimination of Rax in a subset of VMH progenitors results in a cell fate change. $A-L$, In situ hybridization analyses using VMH markers (Sf1, VGlut2, Nkx2.1) and DMH markers (Gad67, $L h x 1, D 1 x 2)$ in both WT $\left(\operatorname{Rax}^{f l o x /+}\right)$ and $R a x$ CKO (Rax flox/null: $\left.K, L\right)$ E12.5 brains are shown. Black brackets mark regions void of VMH + cellular identities and dotted black oval highlights regions where non-VMH markers become misexpressed. $\boldsymbol{M}-\boldsymbol{U}$, The localization of Cre+ cells in relation to VMH markers in Rax CKO generated by crossing Shh:: Cre $^{\text {GFP }} ;$ Rax $^{+ \text {/null }} \times$ Rax $^{\text {floxed/floxed }}$. In situ hybridization using Sf1 riboprobe $(\boldsymbol{M})$ and immunofluorescence of Nkx2.1 $(\boldsymbol{P}, \boldsymbol{S})$ and GFP $(\boldsymbol{N}, \boldsymbol{Q}, \boldsymbol{T})$ on Rax CKO brains (E12.5, E13.5, and P0) is demonstrated. Photoshop was used to digitally merge $\boldsymbol{M}$ and $\boldsymbol{N}, \boldsymbol{P}$ and $\mathbf{Q}$, and $\mathbf{S}$ and $\boldsymbol{T}$ to aid in visualization of the proximity of $\mathrm{GFP}+$ cells and $\mathrm{VMH}$ neurons. White oval denotes VMH doublet $(\boldsymbol{P}, \mathbf{Q})$ and white bracket illustrates the location of $R$ ax mutant cells $(\boldsymbol{N}, \mathbf{O}, \boldsymbol{T}, \boldsymbol{U})$.

Fezf1, Nkx2.1, and VGlut2 (Fig. 7D'-F'). In contrast, Gad67, which labels GABAergic neurons in the $\mathrm{DMH}$ and elsewhere and is normally excluded from the glutamatergic-centric $\mathrm{VMH}$, was ectopically expressed in the center of the Rax CKO VMH (Fig. $\left.7 B^{\prime}, G^{\prime}\right)$. Pomc, which is a selective marker of the ARC, was expressed in its normal ventral expression domain in P0 Rax CKOs (Fig. 7C', $H^{\prime}$ ), suggesting that the non-VMH cells do not acquire an aberrant ARC identity. We thus conclude that Rax is required to confer a VMH identity, with the loss of Rax resulting in a misspecification of $\mathrm{VMH}$ progenitors leading to the ectopic presence of GABAergic neurons.

To ascertain the phenotype of the Rax mutant neurons that failed to adopt a VMH identity, we relied on assaying the expression profile of markers from neighboring regions. In E12.5 hypothalami, a band of cells that failed to express $S f 1$ was observed across the middle of the developing nucleus, with some Sf1expressing neurons detected just above and below this band (Fig. $8 A, B)$. Next, we assayed other VMH markers: VGlut2 (Fig. $8 C, D)$, which labels VMH glutamatergic neurons, and $N k \times 2.1$ (Fig. 8E,F), which demarks both progenitor and postmitotic neurons at this developmental time point, and observed the same band of neurons that fail to express VMH-specific genes in Rax mutant brains. Interestingly, $N k \times 2.1$ expression is maintained throughout VZ in conditional Rax mutants (Fig. $8 F$ ), suggesting that Rax is not required for maintaining $N k \times 2.1+$ progenitors. Next, to determine whether these Rax mutant cells had acquired a different cell fate, we assayed for expression of markers normally found outside the VMH boundary. In fact, Gad67, Lhx1, and $D l \times 2$ are all hypothalamic non-VMH markers (DMH and other regions) and they are all misexpressed within this band of Rax flox/null cells (Fig. 8G-L).

We were struck by the apparent division of the Rax CKO VMH into three distinct clusters: two Sf1 + domains separated by a band of Sf1 - non-VMH cells. We speculated that the Sf1- cells likely arose from the Rax-mutant lineage, while the nearby $S f 1+$ neurons represented the VMH cells that had escaped Rax elimination. Furthermore, we reasoned that the apparent segregation of WT and Rax CKO mutant cells may be due to an alteration of normal cell adhesion properties of the Rax CKO mutant cells. Indeed, the zebrafish Rax ortholog controls the segregative behavior of retinal progenitor cells (Brown et al., 2010) and, in mouse, Rax mutant cells segregate away from WT the developing retina and posterior pituitary (Medina-Martinez et al., 2009), consistent with other regions of the embryonic CNS, where cells segregate due to adhesion differences (Gotz et al., 1996). To test this model further, we examined the location of GFP + cells relative to the VMH markers $S f 1$ and Nkx2.1 in Shh::Cre ${ }^{G F P}$; $R_{a x} x^{f l o x / n u l l}$ embryos at key developmental time points, E12.5, E13.5, and P0 (Fig. 8M-U). At all stages analyzed, we found that GFP+-labeled cells, where Cre is expressed, clustered together between the split $S f 1+($ Fig. $8 M-P$ ) and Nkx2.1+ domains (Fig. $8 P-U)$. To assist in visualization of the approximate location of GFP + cells relative to the VMH marker, we used Photoshop to digitally merge the images from two adjacent sections (Fig. $8 M, N, P, Q, S, T)$. Together, these data are consistent with the notion that Rax flox/null mutant cells segregate from WT lineages, although future work would be required to determine whether this is due to the normal migration pattern of these cells, versus active cell repulsion based on adhesive differences. Combined, our observations suggest that Rax function is required for development of ARC-VMH tuberal hypothalamic cell types.

\section{Discussion}

The ARC and VMH play a key role in maintaining metabolic homeostasis. With the growing obesity epidemic, particularly among children, there is increasing urgency to understand how amplified energy status manifests itself into subtle changes of hypothalamic function. Here, we have conducted 
detailed analyses of Rax expression and used several genetic models to ascertain the functional contribution of Rax in ARC-VMH development, as an entry point toward identifying the molecular mechanisms that underlie establishment of this circuitry. Our results illustrate a functional role for Rax in tuberal hypothalamic development and present a new molecular tool that can be exploited to study plasticity and susceptibility of this brain region.

In this study we demonstrate that Rax is expressed in VMH/ ARC progenitors, where elimination of Rax uniquely in a subset of $\mathrm{VMH}$ progenitors leads to a loss of $\mathrm{VMH}$ neuronal fates and the concomitant ectopic expression of hypothalamic non-VMH cellular markers. There are two possible models (not mutually exclusive) that explain this phenotype in Rax CKO hypothalami: (1) mutant VMH cells transfate into a hypothalamic non-VMH identity, and (2) hypothalamic non-VMH cells migrate into the mutant VMH region. Of these two models, we favor that Raxnull VMH cells have transfated because $N k \times 2.1$ expression in uniquely absent in $\mathrm{VMH}$ postmitotic neurons but is maintained within the surrounding rostral-caudal hypothalamic regions. If neighboring cells were migrating rostrally or caudally into the Rax mutant VMH, then $N k x 2.1$ expression should be detected within the VMH core. However, given that $L h x 1, D l \times 2$, and Gad67 are all DMH markers (in addition to other hypothalamic regions) that are misexpressed in a subset of neurons occupying the VMH core of Rax mutants, it does remain possible that DMH cells migrate ventrally into the VMH of Rax CKO. To conclusively demonstrate that the loss of Rax leads to neuronal misspecification and the acquisition of an aberrant non-VMH hypothalamic identity, future studies need to establish the origin of the $L h \times 1+$ and Dlx2+ cells within the VMH.

Rax mutants display a loss of cellular identity reminiscent of "selector genes," a category of genes that have discrete roles in governing identity of cells types within a lineage compartment. Historically, studies in Drosophila described this class of genes as functioning to specify cell identity within a region of the body plan (Mann and Carroll, 2002), but recently this term has come to be liberally applied to describe transcription factors that direct less discrete programs. $N k \times 2.1$ has a known role in regionalizing the ventral prosencephalon, conferring a broad ventral hypothalamic identity (Sussel et al., 1999; Marín et al., 2002; Manning et al., 2006; Szabó et al., 2009b). But if Nkx2.1 is expressed in progenitors throughout all three rostrocaudal hypothalamic regions during preneurogenesis $(\leq \mathrm{E} 10.5)$, then there must be an additional level of transcriptional code that specifies individual subdomains. This raises the likelihood of selector genes that partition the hypothalamic neuroepithelium. Here we found that Rax is expressed from the onset of hypothalamic development and is limited to progenitors starting with the ARC-VMH primordium and moving caudally toward the mammillary nucleus. In other CNS domains, Rax functions cell autonomously to control cell type-specific properties and establish boundaries (Loosli et al., 2003; Stigloher et al., 2006; Medina-Martinez et al., 2009), and the elimination of the Rax ortholog in zebrafish leads to expansion of rostral hypothalamic boundaries (D.M. Kurrasch, manuscript in preparation). We therefore propose that Rax is a selector gene required to specify mediobasal hypothalamic cell types.

We also discover that Rax expression defines three molecularly distinct progenitor domains along the dorsoventral axis of the E12.5 tuberal hypothalamic region. Our studies here are resemble of those conducted by Jessell and colleagues (Briscoe et al., 2000; Jessell, 2000), whereby spinal neurons derive from a single progenitor domain, but require homeodomain transcription factors as intermediary signals at distinct boundaries along the ven- tricular zone to drive specification of distinct neuronal subtypes. Here, we propose a similar mechanism whereby Rax expression in tuberal hypothalamic progenitor cells seeks to specify subtypes of VMH/ARC postmitotic neurons. Moreover, the absence of Rax expression in domain II also demarks a progenitor pool that we speculate gives rise to DMH neurons. Additional studies examining whether ectopic expression of Rax in nontuberal hypothalamic progenitors results in fate and positional effects of specific neuronal subtypes will be helpful to understand the functional importance of these distinct Rax progenitor domains.

Glutamatergic and GABAergic neurons are the excitatory and inhibitory signals, respectively, in the vertebrate brain (Bennett and Balcar, 1999), and they become organized into discrete domains in a mutually exclusive manner (Bellocchio et al., 2000; Fremeau et al., 2001). To date, main players in the specification of glutamatergic and GABAergic cell fate choices are the proneural basic helix-loop-helix (bHLH) transcription factors Neurogenin (Neurog) 1, Neurog2 and Achaete-scute like 1 (Ascl1; also known as Mash1), respectively (Fode et al., 2000; Schuurmans and Guillemot, 2002). In addition, in the dorsal spinal cord, homeobox genes Tlx 3 and $T l \times 1$ confer excitatory over inhibitory cell fates (Cheng et al., 2004), illustrating a role for homeodomain transcription factors in determining glutamatergic versus GABAergic neuronal fates. Here, VMH neurons are predominantly glutamatergic, with GABAergic cells normally excluded from the VMH core (McClellan et al., 2006). However, the loss of Rax in VMH progenitors leads to a striking loss of glutamatergic neuronal markers and the concomitant misexpression of GABAergic genes uniquely within the VMH core. Future work is required to determine whether Rax directly governs the specification of a glutamate phenotype within the VMH.

Once the hypothalamus becomes regionalized, multipotent progenitors must transition from a preneurogenic stage, when symmetric divisions give rise to proliferative daughter cells, to the neurogenic stage, where a subset of progenitors exit the cell cycle and initiate neuronal differentiation. The expression of bHLH proneural genes is one mechanism by which multipotent progenitors become specified to give rise to individual neuronal fates. Within the tuberal hypothalamus, the proneural gene Ascl1 is expressed in hypothalamic progenitors and is required for the generation of VMH and ARC nuclei (McNay et al., 2006; Kim et al., 2008). Mechanistically, Ascl1 promotes the differentiation of VMH neurons by initiating the expression of $S f 1$, an orphan nuclear receptor that is a pan-VMH marker (Shinoda et al., 1995; Tran et al., 2003; Davis et al., 2004) required for terminal differentiation of VMH neurons (Tran et al., 2003). Indeed, our ongoing studies suggest that Ascll is dysregulated in Rax mutant VMH. Additionally, Neurogenin 3 (Neurog3) in tuberal hypothalamic progenitors is critical for specification of a subset of $\mathrm{VMH}$ and ARC cell types (Pelling et al., 2011). Proneural genes also mediate cell cycle exit and, in cortical progenitor cells, they control progenitor cell maturation independently from their role in regulating neuronal specification (Britz et al., 2006). Thus, given that homeodomain transcription factors function upstream from proneural genes in a hierarchical process regulating cell fate specification in other regions of the embryonic nervous system, we propose that proneural genes likely function downstream of Rax to regulate mediobasal hypothalamic specification in a similar manner.

Studies by Bouret and colleagues have shown that ARC projections are immature at birth but then develop rapidly to form established ARC-DMH circuitry by P6 (Bouret et al., 2004b). Here, we illustrate Rax + fibers extending from the VMH as early 
as E12.5, suggesting that some hypothalamic axonal pathfinding occurs in the embryonic hypothalamus. There are two possibilities to explain the presence of VMH projections at E12.5 (not mutually exclusive): (1) early projections serve some sort of scaffolding role for tangential migration of interneurons or axonal fibers in or out of the developing hypothalamus, but are not forming the actual circuitry that underlies feeding physiologies, and (2) hypothalamic circuits are formed much earlier than previously appreciated. Given that gestational environment can influence future metabolic imbalance in offspring (Levin, 2006; Viveros et al., 2010; Ferretti et al., 2011), we propose that at least some hypothalamic feeding circuits are established during neurogenesis.

In summary, our data demonstrate that Rax serves as a selector gene to determine mediobasal neuronal identities. Our studies also show that Rax genetic tools can be exploited to study the ontology and establishment of VMH-ARC cell types and circuits.

\section{References}

Altman J, Bayer SA (1986) The development of the rat hypothalamus. Adv Anat Embryol Cell Biol 100:1-178. CrossRef Medline

Andreazzoli M, Gestri G, Cremisi F, Casarosa S, Dawid IB, Barsacchi G (2003) Xrx1 controls proliferation and neurogenesis in Xenopus anterior neural plate. Development 130:5143-5154. CrossRef Medline

Badea TC, Nathans J (2004) Quantitative analysis of neuronal morphologies in the mouse retina visualized by using a genetically directed reporter. J Comp Neurol 480:331-351. CrossRef Medline

Bellocchio EE, Reimer RJ, Fremeau RT Jr, Edwards RH (2000) Uptake of glutamate into synaptic vesicles by an inorganic phosphate transporter. Science 289:957-960. CrossRef Medline

Bennett MR, Balcar VJ (1999) Forty years of amino acid transmission in the brain. Neurochem Int 35:269-280. CrossRef Medline

Bouret SG, Draper SJ, Simerly RB (2004a) Trophic action of leptin on hypothalamic neurons that regulate feeding. Science 304:108-110. CrossRef Medline

Bouret SG, Draper SJ, Simerly RB (2004b) Formation of projection pathways from the arcuate nucleus of the hypothalamus to hypothalamic regions implicated in the neural control of feeding behavior in mice. J Neurosci 24:2797-2805. CrossRef Medline

Briscoe J, Pierani A, Jessell TM, Ericson J (2000) A homeodomain protein code specifies progenitor cell identity and neuronal fate in the ventral neural tube. Cell 101:435-445. CrossRef Medline

Britz O, Mattar P, Nguyen L, Langevin LM, Zimmer C, Alam S, Guillemot F, Schuurmans C (2006) A role for proneural genes in the maturation of cortical progenitor cells. Cereb Cortex 16 [Suppl 1]:i138-i151. Medline

Brown KE, Keller PJ, Ramialison M, Rembold M, Stelzer EH, Loosli F, Wittbrodt J (2010) Nlcam modulates midline convergence during anterior neural plate morphogenesis. Dev Biol 339:14-25. CrossRef Medline

Canteras NS, Simerly RB, Swanson LW (1994) Organization of projections from the ventromedial nucleus of the hypothalamus: a phaseolus vulgaris-leucoagglutinin study in the rat. J Comp Neurol 348:41-79. CrossRef Medline

Caqueret A, Coumailleau P, Michaud JL (2005) Regionalization of the anterior hypothalamus in the chick embryo. Dev Dyn 233:652-658. CrossRef Medline

Caqueret A, Boucher F, Michaud JL (2006) Laminar organization of the early developing anterior hypothalamus. Dev Biol 298:95-106. CrossRef Medline

Casarosa S, Amato MA, Andreazzoli M, Gestri G, Barsacchi G, Cremisi F (2003) Xrx1 controls proliferation and multipotency of retinal progenitors. Mol Cell Neurosci 22:25-36. CrossRef Medline

Cheng L, Arata A, Mizuguchi R, Qian Y, Karunaratne A, Gray PA, Arata S, Shirasawa S, Bouchard M, Luo P, Chen CL, Busslinger M, Goulding M, Onimaru H, Ma Q (2004) Tlx3 and Tlx1 are post-mitotic selector genes determining glutamatergic over GABAergic cell fates. Nat Neurosci 7:510-517. CrossRef Medline

Cheung CC, Kurrasch DM, Liang JK, Ingraham HA (2012) Genetic labeling of SF-1 neurons in mice reveals VMH circuitry beginning at neurogenesis and development of a separate non-SF-1 neuronal cluster in the ventro- lateral VMH. J Comp Neurol. Advance online publication. Retrieved Nov. 22, 2012. doi:10.1002/cne.23226. CrossRef Medline

Davis AM, Seney ML, Stallings NR, Zhao L, Parker KL, Tobet SA (2004) Loss of steroidogenic factor 1 alters cellular topography in the mouse ventromedial nucleus of the hypothalamus. J Neurobiol 60:424-436. CrossRef Medline

Elias CF, Aschkenasi C, Lee C, Kelly J, Ahima RS, Bjorbaek C, Flier JS, Saper CB, Elmquist JK (1999) Leptin differentially regulates NPY and POMC neurons projecting to the lateral hypothalamic area. Neuron 23:775-786. CrossRef Medline

Eriksson KS, Mignot E (2009) T-box 3 is expressed in the adult mouse hypothalamus and medulla. Brain Res 1302:233-239. CrossRef Medline

Ferretti S, Fornari A, Pedrazzi P, Pellegrini M, Zoli M (2011) Developmental overfeeding alters hypothalamic neuropeptide mRNA levels and response to a high-fat diet in adult mice. Peptides 32:1371-1383. CrossRef Medline

Fields-Berry SC, Halliday AL, Cepko CL (1992) A recombinant retrovirus encoding alkaline phosphatase confirms clonal boundary assignment in lineage analysis of murine retina. Proc Natl Acad Sci U S A 89:693-697. CrossRef Medline

Fode C, Ma Q, Casarosa S, Ang SL, Anderson DJ, Guillemot F (2000) A role for neural determination genes in specifying the dorsoventral identity of telencephalic neurons. Genes Dev 14:67-80. Medline

Fremeau RT Jr, Troyer MD, Pahner I, Nygaard GO, Tran CH, Reimer RJ, Bellocchio EE, Fortin D, Storm-Mathisen J, Edwards RH (2001) The expression of vesicular glutamate transporters defines two classes of excitatory synapse. Neuron 31:247-260. CrossRef Medline

Furukawa T, Kozak CA, Cepko CL (1997) rax, a novel paired-type homeobox gene, shows expression in the anterior neural fold and developing retina. Proc Natl Acad Sci U S A 94:3088-3093. CrossRef Medline

Furuta Y, Lagutin O, Hogan BL, Oliver GC (2000) Retina- and ventral forebrain-specific Cre recombinase activity in transgenic mice. Genesis 26:130-132. CrossRef Medline

Geng X, Speirs C, Lagutin O, Inbal A, Liu W, Solnica-Krezel L, Jeong Y, Epstein DJ, Oliver G (2008) Haploinsufficiency of Six3 fails to activate Sonic hedgehog expression in the ventral forebrain and causes holoprosencephaly. Dev Cell 15:236-247. CrossRef Medline

Gotz M, Wizenmann A, Reinhardt S, Lumsden A, Price J (1996) Selective adhesion of cells from different telencephalic regions. Neuron 16:551564. CrossRef Medline

Harfe BD, Scherz PJ, Nissim S, Tian H, McMahon AP, Tabin CJ (2004) Evidence for an expansion-based temporal Shh gradient in specifying vertebrate digit identities. Cell 118:517-528. CrossRef Medline

Hirata T, Suda Y, Nakao K, Narimatsu M, Hirano T, Hibi M (2004) Zinc finger gene fez-like functions in the formation of subplate neurons and thalamocortical axons. Dev Dyn 230:546-556. CrossRef Medline

Hirata T, Nakazawa M, Muraoka O, Nakayama R, Suda Y, Hibi M (2006) Zinc-finger genes Fez and Fez-like function in the establishment of diencephalon subdivisions. Development 133:3993-4004. CrossRef Medline

Ifft JD (1972) An autoradiographic study of the time of final division of neurons in rat hypothalamic nuclei. J Comp Neurol 144:193-204. CrossRef Medline

Ikeda Y, Takeda Y, Shikayama T, Mukai T, Hisano S, Morohashi KI (2001) Comparative localization of Dax-1 and Ad4BP/SF-1 during development of the hypothalamic-pituitary-gonadal axis suggests their closely related and distinct functions. Dev Dyn 220:363-376. CrossRef Medline

Jessell TM (2000) Neuronal specification in the spinal cord: inductive signals and transcriptional codes. Nat Rev Genet 1:20-29. CrossRef Medline

Kaufman M (1992) The atlas of mouse development. London: Academic.

Kennedy BN, Stearns GW, Smyth VA, Ramamurthy V, van Eeden F, Ankoudinova I, Raible D, Hurley JB, Brockerhoff SE (2004) Zebrafish rx3 and mab21l2 are required during eye morphogenesis. Dev Biol 270:336349. CrossRef Medline

Kim EJ, Battiste J, Nakagawa Y, Johnson JE (2008) Ascl1 (Mash1) lineage cells contribute to discrete cell populations in CNS architecture. Mol Cell Neurosci 38:595-606. CrossRef Medline

Kurrasch DM, Cheung CC, Lee FY, Tran PV, Hata K, Ingraham HA (2007) The neonatal ventromedial hypothalamus transcriptome reveals novel markers with spatially distinct patterning. J Neurosci 27:13624-13634. CrossRef Medline

Lagutin OV, Zhu CC, Kobayashi D, Topczewski J, Shimamura K, Puelles L, Russell HR, McKinnon PJ, Solnica-Krezel L, Oliver G (2003) Six3 repression of Wnt signaling in the anterior neuroectoderm is essential for 
vertebrate forebrain development. Genes Dev 17:368-379. CrossRef Medline

Lee MK, Tuttle JB, Rebhun LI, Cleveland DW, Frankfurter A (1990) The expression and posttranslational modification of a neuron-specific betatubulin isotype during chick embryogenesis. Cell Motil Cytoskeleton 17: 118-132. CrossRef Medline

Levin BE (2006) Metabolic imprinting: critical impact of the perinatal environment on the regulation of energy homeostasis. Philos Trans R Soc Lond B Biol Sci 361:1107-1121. CrossRef Medline

Lobe CG, Koop KE, Kreppner W, Lomeli H, Gertsenstein M, Nagy A (1999) Z/AP, a double reporter for cre-mediated recombination. Dev Biol 208: 281-292. CrossRef Medline

Loosli F, Staub W, Finger-Baier KC, Ober EA, Verkade H, Wittbrodt J, Baier $\mathrm{H}$ (2003) Loss of eyes in zebrafish caused by mutation of chokh/rx3. EMBO Rep 4:894-899. CrossRef Medline

Mann RS, Carroll SB (2002) Molecular mechanisms of selector gene function and evolution. Curr Opin Genet Dev 12:592-600. CrossRef Medline

Manning L, Ohyama K, Saeger B, Hatano O, Wilson SA, Logan M, Placzek M (2006) Regional morphogenesis in the hypothalamus: a BMP-Tbx2 pathway coordinates fate and proliferation through Shh downregulation. Dev Cell 11:873-885. CrossRef Medline

Marín O, Baker J, Puelles L, Rubenstein JL (2002) Patterning of the basal telencephalon and hypothalamus is essential for guidance of cortical projections. Development 129:761-773. Medline

Mathers PH, Grinberg A, Mahon KA, Jamrich M (1997) The Rx homeobox gene is essential for vertebrate eye development. Nature 387:603-607. CrossRef Medline

Matsuda T, Cepko CL (2004) Electroporation and RNA interference in the rodent retina in vivo and in vitro. Proc Natl Acad Sci U S A 101:16-22. CrossRef Medline

McClellan KM, Parker KL, Tobet S (2006) Development of the ventromedial nucleus of the hypothalamus. Front Neuroendocrinol 27:193-209. CrossRef Medline

McNay DE, Pelling M, Claxton S, Guillemot F, Ang SL (2006) Mash1 is required for generic and subtype differentiation of hypothalamic neuroendocrine cells. Mol Endocrinol 20:1623-1632. Medline

Medina-Martinez O, Amaya-Manzanares F, Liu C, Mendoza M, Shah R, Zhang L, Behringer RR, Mahon KA, Jamrich M (2009) Cellautonomous requirement for $\mathrm{rx}$ function in the mammalian retina and posterior pituitary. PLoS One 4:e4513. CrossRef Medline

Muranishi Y, Terada K, Inoue T, Katoh K, Tsujii T, Sanuki R, Kurokawa D, Aizawa S, Tamaki Y, Furukawa T (2011) An essential role for RAX homeoprotein and NOTCH-HES signaling in Otx2 expression in embryonic retinal photoreceptor cell fate determination. J Neurosci 31: 16792-16807. CrossRef Medline

Muranishi Y, Terada K, Furukawa T (2012) An essential role for Rax in retina and neuroendocrine system development. Dev Growth Differ 54: 341-348. CrossRef Medline

Oliver G, Mailhos A, Wehr R, Copeland NG, Jenkins NA, Gruss P (1995) Six3, a murine homologue of the sine oculis gene, demarcates the most anterior border of the developing neural plate and is expressed during eye development. Development 121:4045-4055. Medline

Padilla SL, Carmody JS, Zeltser LM (2010) Pomc-expressing progenitors give rise to antagonistic neuronal populations in hypothalamic feeding circuits. Nat Med 16:403-405. CrossRef Medline

Pelling M, Anthwal N, McNay D, Gradwohl G, Leiter AB, Guillemot F, Ang SL (2011) Differential requirements for neurogenin 3 in the development of POMC and NPY neurons in the hypothalamus. Dev Biol 349:406-416. CrossRef Medline

Saper CB, Swanson LW, Cowan WM (1979) Some efferent connections of the rostral hypothalamus in the squirrel monkey (Saimiri sciureus) and cat. J Comp Neurol 184:205-241. CrossRef Medline

Schuurmans C, Guillemot F (2002) Molecular mechanisms underlying cell fate specification in the developing telencephalon. Curr Opin Neurobiol 12:26-34. CrossRef Medline

Shimada M, Nakamura T (1973) Time of neuron origin in mouse hypothalamic nuclei. Exp Neurol 41:163-173. CrossRef Medline

Shimamura K, Hartigan DJ, Martinez S, Puelles L, Rubenstein JL (1995) Longitudinal organization of the anterior neural plate and neural tube. Development 121:3923-3933. Medline
Shimogori T, Lee DA, Miranda-Angulo A, Yang Y, Wang H, Jiang L, Yoshida AC, Kataoka A, Mashiko H, Avetisyan M, Qi L, Qian J, Blackshaw S (2010) A genomic atlas of mouse hypothalamic development. Nat Neurosci 13:767-775. CrossRef Medline

Shinoda K, Lei H, Yoshii H, Nomura M, Nagano M, Shiba H, Sasaki H, Osawa Y, Ninomiya Y, Niwa O (1995) Developmental defects of the ventromedial hypothalamic nucleus and pituitary gonadotroph in the Ftz-F1 disrupted mice. Dev Dyn 204:22-29. CrossRef Medline

Stenman J, Yu RT, Evans RM, Campbell K (2003) Tlx and Pax6 co-operate genetically to establish the pallio-subpallial boundary in the embryonic mouse telencephalon. Development 130:1113-1122. CrossRef Medline

Stigloher C, Ninkovic J, Laplante M, Geling A, Tannhäuser B, Topp S, Kikuta H, Becker TS, Houart C, Bally-Cuif L (2006) Segregation of telencephalic and eye-field identities inside the zebrafish forebrain territory is controlled by Rx3. Development 133:2925-2935. CrossRef Medline

Sussel L, Marin O, Kimura S, Rubenstein JL (1999) Loss of Nkx2.1 homeobox gene function results in a ventral to dorsal molecular respecification within the basal telencephalon: evidence for a transformation of the pallidum into the striatum. Development 126:3359-3370. Medline

Swindell EC, Bailey TJ, Loosli F, Liu C, Amaya-Manzanares F, Mahon KA, Wittbrodt J, Jamrich M (2006) Rx-Cre, a tool for inactivation of gene expression in the developing retina. Genesis 44:361-363. CrossRef Medline

Szabó NE, Zhao T, Zhou X, Alvarez-Bolado G (2009a) The role of Sonic hedgehog of neural origin in thalamic differentiation in the mouse. J Neurosci 29:2453-2466. CrossRef Medline

Szabó NE, Zhao T, Cankaya M, Theil T, Zhou X, Alvarez-Bolado G (2009b) Role of neuroepithelial Sonic hedgehog in hypothalamic patterning. J Neurosci 29:6989-7002. CrossRef Medline

Thompson RH, Swanson LW (1998) Organization of inputs to the dorsomedial nucleus of the hypothalamus: a reexamination with Fluorogold and PHAL in the rat. Brain Res Brain Res Rev 27:89-118. Medline

Tran PV, Lee MB, Marín O, Xu B, Jones KR, Reichardt LF, Rubenstein JR, Ingraham HA (2003) Requirement of the orphan nuclear receptor SF-1 in terminal differentiation of ventromedial hypothalamic neurons. Mol Cell Neurosci 22:441-453. CrossRef Medline

Tucker P, Laemle L, Munson A, Kanekar S, Oliver ER, Brown N, Schlecht H, Vetter M, Glaser T (2001) The eyeless mouse mutation (ey1) removes an alternative start codon from the Rx/rax homeobox gene. Genesis 31:4353. CrossRef Medline

VanDunk C, Hunter LA, Gray PA (2011) Development, maturation, and necessity of transcription factors in the mouse suprachiasmatic nucleus. J Neurosci 31:6457-6467. CrossRef Medline

Viveros MP, Díaz F, Mateos B, Rodríguez N, Chowen JA (2010) Maternal deprivation induces a rapid decline in circulating leptin levels and sexually dimorphic modifications in hypothalamic trophic factors and cell turnover. Horm Behav 57:405-414. CrossRef Medline

Voronina VA, Kozhemyakina EA, O'Kernick CM, Kahn ND, Wenger SL, Linberg JV, Schneider AS, Mathers PH (2004) Mutations in the human RAX homeobox gene in a patient with anophthalmia and sclerocornea. Hum Mol Genet 13:315-322. Medline

Voronina VA, Kozlov S, Mathers PH, Lewandoski M (2005) Conditional alleles for activation and inactivation of the mouse Rx homeobox gene. Genesis 41:160-164. CrossRef Medline

Wataya T, Ando S, Muguruma K, Ikeda H, Watanabe K, Eiraku M, Kawada M, Takahashi J, Hashimoto N, Sasai Y (2008) Minimization of exogenous signals in ES cell culture induces rostral hypothalamic differentiation. Proc Natl Acad Sci U S A 105:11796-11801. CrossRef Medline

Wong YW, Low MG (1994) Biosynthesis of glycosylphosphatidylinositolanchored human placental alkaline phosphatase: evidence for a phospholipase C-sensitive precursor and its post-attachment conversion into a phospholipase C-resistant form. Biochem J 301:205-209. Medline

Zhang L, Mathers PH, Jamrich M (2000) Function of Rx, but not Pax6, is essential for the formation of retinal progenitor cells in mice. Genesis 28:135-142. CrossRef Medline

Zhang XM, Ramalho-Santos M, McMahon AP (2001) Smoothened mutants reveal redundant roles for Shh and Ihh signaling including regulation of L/R symmetry by the mouse node. Cell 106:781-792. Medline 